\title{
5. The Failing Family: Changing Constellations of Gender, Intimacy, and Genre
}

\begin{abstract}
This chapter examines a boundary-crossing archive of popular and countercinematic West, East, and post-unification German films that all focus on precarious intimacies: Dörrie's Men (1985); Wortmann's Maybe...Maybe Not (1994); Carow's Coming Out (1989); and Grisebach's Longing (2006). Shifting focus onto a consideration of men and masculinity in the postfeminist era, I analyze how these films subject the heteropatriarchal family to scrutiny, often exploring homosocial bonds and queer relations. In addition to investigating the precaritization of gender, sexuality, and intimacy pictured by these four films, this chapter sheds new light on the much vaunted "return to genre" in the German cinema of neoliberalism.
\end{abstract}

Keywords: Doris Dörrie, Sönke Wortmann, Heiner Carow, Valeska Grisebach, precarious intimacy, queer film

Doris Dörrie's Männer (Men), a low-budget comedy co-produced by the television channel ZDF for less than half a million dollars, went on to become one of the top box-office draws of 1985 in West Germany, where it beat out Hollywood blockbusters including Rocky II and Back to the Future, selling more than five million tickets and contributing to German film's sensational 30.9 percent domestic market share that year. ${ }^{1}$ The success of Männer signalled a change in constellations of gender, intimacy, and genre in German cinema, debuting a template that came to predominate

1 See http://www.insidekino.com/DJahr/D1985.htm. The success of Männer was superceded only by the success of that year's number one hit Otto - Der Film, co-directed by Xaver Schwarzenberger and the comedian Otto Waalkes.

Baer, H., German Cinema in the Age of Neoliberalism. Amsterdam: Amsterdam University Press, 2021. DOI: 10.5117/9789463727334_CHO5 
in the most successful films of the following decade and beyond. These Beziehungskomödien (relationship comedies) typically focused on men and masculinity in the postfeminist era, employing love triangles to explore homosocial bonds and queer intimacies among men, and subjecting the heteropatriarchal family to scrutiny. Often 'amphibic' in their production context (i.e. co-produced by television and designed to succeed on both the small and the large screen), these films exhibit hybridity along multiple registers. Combining slapstick comedy with a melancholic tone, they are also ideologically ambiguous in their portrayal of the co-existence of traditional and flexible gender roles and sexual norms characteristic of neoliberalism.

As Dörrie described it retrospectively in a 2000 interview, the immense success of Männer hailed from its precise diagnosis of the Zeitgeist: 'I think that was one of the reasons why this film became so successful, not only in Germany but really worldwide; that it hit the right moment. It was the moment of abandoning political ideas, and becoming more adjusted to the way capitalism works in the end. ${ }^{2}$ With its story of male transformation through the rejection of alternative lifestyle formations that had been characteristic of the post-1968 era and the concomitant embrace of business masculinity and flexible labour, Männer is a neoliberal fairy tale that narrativizes the socioeconomic transition toward a new conservatism in Western societies during the 1980s, encapsulated in the Federal Republic by Helmut Kohl's promotion of the leistungsbereiten Normalbürger [competitive average citizen]. ${ }^{3}$ Insofar as Männer depicts the abandonment of 'political ideas' associated with 1968, then, at the same time it makes visible the rise of a new set of political ideas in the wake of the neoliberal turn.

That Männer stages these political ideas through the story of a failing family is certainly no accident. While the neoconservatism of the Kohl/ Reagan/Thatcher era paid lip service to defending traditional 'family values', in fact shifting conceptions of family, intimacy, and caregiving — which went hand in hand with changing norms around gender and sexuality-were crucial to the privatization of social reproduction as a matter of personal responsibility (rather than state provision) that emerged as a trademark of these neoliberal regimes. Volker Woltersdorff has argued that the intensification of neoliberal governmentality in Western societies since the 1980 s gives rise to 'precarious sexualities', a simultaneous strengthening and destabilizing of heteronormativity, since 'the neo-liberal flexibilization of 
gender and sexual identities allows traditional and flexible gender roles to coexist'. ${ }^{4}$ As Woltersdorff suggests, the neoliberal discourse of mobility and deregulation appears to open up spaces for non-normative gender identifications, sexual practices, and affective ties, but the institutional sex-gender system is still an imperative, creating a situation of permanent insecurity. Woltersdorff describes how the state increasingly promotes non-monogamy as a way of delegating to new kinds of alliances support and caretaking formerly underwritten by social welfare. While this brings the affordances of sexual mobility and choice as well as the possibility of new social formations and domestic partnerships, 'Social lack of solidarity proves to be a historical condition for the recognition and normalization of non-marital lifestyles and moves within the neo-liberal constellation of gains in industrialization and risk growth. ${ }^{5}$ Thus, sexual and familial 'choice' is possible so long as one assumes the personal responsibility and social risk they entail, since individualization and the privatization of caregiving go hand in hand.

The genre of the Beziehungskömodie charts the transformation in family and caregiving structures and notions of intimacy across the period of neoliberal transition. Arguing that its generic interventions connect to the relationship comedy's imaging of precarious sexualities, this chapter considers the two most popular exemplars of the genre, Männer and Der bewegte Mann (The Moved Man, 1994; released in English as Maybe... Maybe Not), directed by Sönke Wortmann, which became the top-grossing domestic film of the 1990s in unified Germany. I examine these popular comedies in connection with two important films that diverge from the Beziehungskomödie substantially in terms of form, but which also archive the failing family and transformations in gender, sexuality, and intimacy through interrogations of genre: the first East German feature film about homosexuality, Heiner Carow's 1989 DEFA film Coming Out; and Valeska Grisebach's breakthrough Berlin School film Sehnsucht (Longing, 2006), which traces the alterations to ordinary life in a rural eastern German town after unification. In contrast to the predominant tendency to gender neoliberalism female by focusing on women protagonists, the four films analysed in this chapter share a notable focus on men and masculinity. Likewise, in all four films, the bed functions as a symbolic space both for representing the transformation of intimacy in neoliberalism and for testing out non-normative images of gender and sexuality on screen. 
While this grouping might appear curious upon first look, reading these four films together not only makes visible changing modes of affect and intimacy in the era of precarious sexualities, but it also sheds new light on the much vaunted 'return to genre' in German cinema of the late 2 th and early 21st-first centuries. In his introduction to Generic Histories of German Cinema: Genre and Its Deviations, Jaimey Fisher points out that studies of genre in the German context have tended to focus only on mainstream, commercial films at the expense of considering how the operations of genre are relevant across a broader cinematic spectrum: '[A]ny investigation of the history of genre should [...] reconceptualize film history in a way that can pertain to both popular and art cinema. ${ }^{6}$ The reconceptualization that Fisher calls for is especially important at a moment characterized by the erosion of traditional distinctions between the twin poles of popular and art cinema-an erosion that is evident not least in the very overt play with genre that characterizes contemporary 'postcinema'.7

This chapter and the next therefore emphasize how a broad range of stylistically divergent films marked by different production cultures intervene into genre conventions, often engaging with them self-reflexively and/or disorganizing them in ways that are emblematic for the German cinema of neoliberalism. Thus, while Coming Out and Sehnsucht do not conform to the generic conventions of the Beziehungskomödie, my analysis demonstrates how they anticipate or reflect on these conventions in ways that recall Rick Altman's notion of 'genrefication as process': 'the constant category-splitting/category-creating dialectic' through which genres unfold, consolidate, and morph again. ${ }^{8}$

My analysis develops genre as a conceptual framework for capturing a sense of the historical present, in resonance with Lauren Berlant's attention to genre in Cruel Optimism. As we have seen, Berlant develops new paradigms for considering both contemporary aesthetic production and the present as such, focusing on the question of why people persist in attaching to normative paradigms even when these normativities do them harm. Berlant suggests that the rise of neoliberalism is accompanied by the emergence of new aesthetic and generic forms that attend to the pervasive precariousness, crisis, and loss that characterize contemporary experience. In considering

6 Fisher, Generic Histories of German Cinema, 3.

7 Steven Shaviro has asserted that 'Digital technologies, together with neoliberal economic relations, have given birth to radically new ways of manufacturing and articulating lived experience', an emergent media regime that he calls 'post-cinema'. See Shaviro, Post-Cinematic Affect, 2. 8 Altman, Film/Genre, 65. 
how cultural productions track the transformations of the historical present, she describes the 'waning of genre, and in particular older realist genres [...] whose conventions of relating fantasy to ordinary life and whose depictions of the good life now appear to mark archaic expectations about having and building a life. Genres provide an affective expectation of the experience of watching something unfold, whether that thing is in life or in art.9 In this regard, genre becomes a key mode for charting the disjunction between archaic and emergent conventions of relating fantasy to ordinary life, a way of making visible the 'unbinding of subjects from their economic and intimate optimism. ${ }^{10}$ Berlant's conception of genre as an affectively-charged horizon of expectations around how a narrative will unfold, and as a space for charting changing conventions regarding the interplay of fantasy and ordinary life, helps to describe my approach to examining the failing family and the precaritization of sexuality in Männer, Der bewegte Mann, Coming Out, and Sehnsucht.

\section{Männer and the Rise of Business Masculinity}

A symptomatic film for the emergent era of 'postfeminism', Männer turns its lens on modern masculinity in the West German 1980s. Discovering on the day of their wedding anniversary that his wife has a lover on the side, advertising executive Julius (Heiner Lauterbach) — who is outraged by this transgression despite his own infidelities - sets out to determine what appeal his wife's lover Stefan (Uwe Ochsenknecht) possesses that Julius himself lacks. Following and spying on his rival, Julius discovers that Stefan is searching for a new roommate, and he promptly offers to move in. At close quarters, Julius observes Stefan's impulsiveness and laxity, but what begins as a classic 'odd couple' set-up soon shifts to a Pygmalion tale as Julius sets out to transform Stefan into an exemplar of the new business masculinity. Moulding Stefan in his own image, Julius produces a man who can match him professionally, if not personally, since Julius's wife Paula (Ulrike Kiener) serves merely as an excuse for what emerges as the film's real focus: cultivating a spirit of competition between men to replace the social solidarity that Stefan - with his long hair, countercultural attitude, and communal apartment-initially appears to embody.Julius trains Stefan in the hallmarks of commercially profitable art, teaches him successful 
interview practices, and introduces Stefan to his own professional network. Most crucially of all, Julius buys Stefan a suit and cuts his hair, reshaping his corporeal presence and schooling him in the 1980 s art of dressing for success.

Julius's reshaping of Stefan operates as an allegory for the side-lining, under the sign of the neoliberal turn, of social differences, alternative lifestyles, and emancipatory politics associated with the post-1968 period. As Gertrud Koch pointed out already in 1986, in contrast to other popular German comedies, Männer draws its humour precisely from the way it embraces the new aesthetic and political mainstream: 'The consensus that delights everyone is the notion that the fusty leftist atmosphere has finally been shaken off', especially the fustiness associated with feminism - and precisely in a film written and directed by a woman. ${ }^{11}$ What replaces this fusty atmosphere is an invigorated sphere of business activity occupied by a new-style homo oeconomicus, a competitive subject and entrepreneur of the self.

Männer opens with an emblematic shot recalling the heyday of industrial capitalism: an all-female typing pool. With its clanging sounds of soon-to-be obsolete machinery, this deliberately (almost) anachronistic workplace imagery, marked by rigidly defined spheres, will be exposed as outmoded by the end of the film. ${ }^{12}$ Here, the gendered division of labour is underscored by a male voice on the intercom, the boss calling one of the typists into his office. As she enters, the camera dwells on the sign affixed to his office door, a harbinger of globalization reading, in English, 'Creative Director, Julius Armbrust'. With its conventional depiction of the 2oth-century office, this opening sequence contrasts sharply with the final sequence of Männer, also set in Julius's advertising firm, which reconfigures the contemporary workplace as a site of flexibility and self-management. Ultimately, Stefan-exhibiting a combination of hippie spontaneity and professional traits adopted from Julius-emerges as ideally suited for the dynamics of the modern workplace, an early example of the 'creative class' (Richard Florida) who is poised to displace the top-down managerial style embodied by Julius himself.

While Männer thus pits two male types against one another in the quest for success in business, there is never any doubt that both of them will pursue this type of success. Indeed, though he is at first introduced as attractive to Paula because of his divergence from business masculinity, Stefan-who 
has been subsidizing his artistic pursuits with a fast-food job-expresses his interest in management to Julius soon after they meet. Julius, who is fond of uttering managerial slogans ('I don't suffer from problems, I do away with them') subjects Stefan to the 'paper-hat challenge', a business test that ostensibly reveals Stefan to be a follower rather than a leader. Though he labels Stefan a 'loser', Julius takes on the challenge of turning him into a winner in order to demonstrate the truth behind his own neoliberal mantra of personal responsibility: 'Every person is fundamentally free. If he isn't free, the fault is his own.'

Notably, the crucial scene of transformation, in which Stefan begins to model the traits associated with business masculinity, assuming the affective and corporeal style of the manager by literally dressing up as Julius, occurs in a remarkable scene of emotional and physical intimacy between the two men as they lie in bed together. This pivotal sequence of Männer begins in one bed and concludes in another, drawing attention to the bed as a symbolic space for representing new intimacies in the era of precarious sexualities. At the outset, we see the two protagonists lying together in a large bed, drinking beer and watching ice hockey on television in a ritual of male bonding. Notably, both men exhibit various states of undress: Julius, with his pants undone, lounges next to Stefan, who wears nothing but an open bathrobe and a pair of leopard-spot underpants that leave little to the imagination. Throughout the sequence, Stefan's hands are bandaged, the result of a kitchen 'accident' in which Julius - after hearing Stefan talk about Paula-has poured boiling water into the sink where Stefan is washing dishes, burning and symbolically castrating him. As a result of Stefan's injury, he is rendered passive, offering a narrative motivation for Julius to actively care for him, albeit in a way that conflates intimacy and competition.

In a series of long takes, the men argue about Julius's claim that Stefan is a loser whose lack of success stems from his failure to responsibilize and perform appropriately. To prove his point, Julius leaves the room and returns with his own bespoke suit, prompting Stefan to don the suit, slick back his hair, and perform as a model manager. In a two shot, we see the men contemplating Stefan's reflection in the mirror; as Julius reaches both arms around Stefan's waist to adjust his pants, he comments, 'If I were a woman and saw you on the street....' 'You'd immediately fall in love with me!', Stefan replies, completing the sentence. Here, as elsewhere in the sequence, Julius discursively adopts the position of a woman in order to legitimate his expression of desire for Stefan. In response, Stefan dons a hairy gorilla mask that he finds in the wardrobe, at once an avatar of and disguise for his 


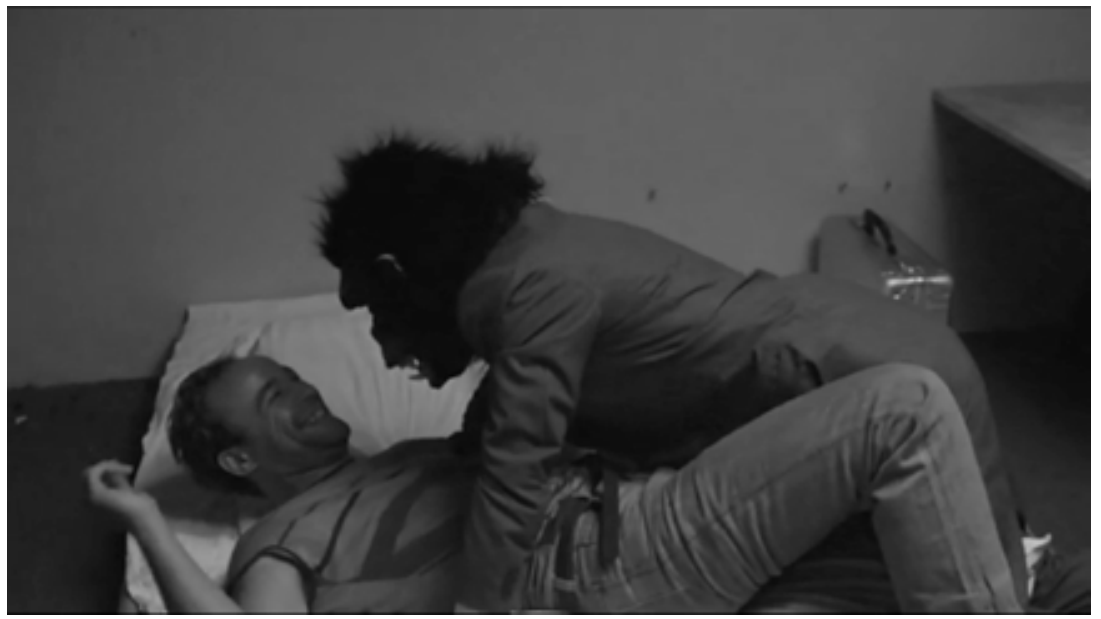

11. Flexibilized sexuality in Doris Dörrie's Männer (Men, 1985): Stefan (Uwe Ochsenknecht) and Julius (Heiner Lauterbach) share an intimate moment in bed.

own 'animal' desire; as the soundtrack surges and the pace of the editing accelerates, Stefan chases Julius, who flees in mock fear only to leap into Stefan's embrace, wrapping his arms and legs around the other man, who grunts and groans as he spins Julius around. Here, homosocial bonding verges into overt physical intimacy, as Stefan throws Julius down onto a mattress that is lying on the floor, pressing his body into the other man and kissing him (albeit through the gorilla mask). Laughing and grinding on the mattress, both men ever so briefly give in to their mutual attraction, which subsequently forms the foundation for Stefan's process of becoming (like) Julius (see Illustration 11).

Coined by the sociologist of gender Raewyn Connell, the term 'transnational business masculinity' describes 'the hegemonic form of masculinity in the current world gender order' and the dominant masculinity of neoliberalism, one that is shared by the business executives of global capitalism and the political executives who interact with them. ${ }^{13}$ According to Connell, business masculinity is characterized by 'an increasing egocentrism, very conditional loyalties (even to the corporation), and a declining sense of responsibility for others (except for the purposes of image making)'; its exemplary subject is 'a person with no permanent commitments, except (in effect) to the idea of accumulation itself'. ${ }^{14}$ Moreover, what specifically differentiates transnational business masculinity from traditional bourgeois 
masculinity in Connell's account is an increasingly flexibilized sexuality, 'with a growing tendency to commodify relations with women'. ${ }^{15}$ Unlike the traditional patriarch, then, the neoliberal avatar of business masculinity is not defined by his familial relations or sexual attachments. Just as he views the accumulation of wealth as an end in itself rather than as a way of providing for his heirs, his sexual relations are transactional rather than oriented toward the perpetuation of the family lineage.

Transnational business masculinity, a mode of entrepreneurial selfhood linked to flexibility, choice, and individualism, thus breaks with traditional patriarchal masculinity and enables new forms of intimacy. However, per Woltersdorff's characterization of neoliberal sexualities as precarious and contradictory, the flexibilization associated with transnational business masculinity produces both new opportunities for non-traditional lifestyles and new normativities that result from the demand for 'mobile working subjects who are in a position to construct and disband affective ties effortlessly'. ${ }^{16}$ Thus, intimate relations are always subordinated to the primacy of business.

In the case of Männer, we find a kind of distributed intimacy that is repeatedly constructed and disbanded in the course of the narrative, as we see varying couples form and break up: Paula and Julius, Paula and Stefan, Stefan and Julius, then Paula and Julius again. While the film draws its comedic force from the contrivances and reversals of the love triangle, ultimately these shifting intimacies all facilitate the production and enforcement of Stefan as a subject of masculine business capitalism. As Holger Römers has suggested, Männer makes visible the performative construction of gender: 'By involving her men in a series of masquerades, Dörrie foregrounds the performativity of their masculinity and their identities in general. ${ }^{17}$ For instance, Stefan asks Julius, 'I'm wondering, which is the costume: your suit or your jeans?' To which Julius pointedly replies, 'Both', emphasizing the breakdown of distinctions between work and leisure in the performance of business masculinity.

Costuming and masquerade also play a key role in the pivotal scene when Paula pays a surprise morning visit to the apartment, catching Stefan and Julius off guard. So that she won't recognize him, Julius dons the gorilla mask and a pair of boxing gloves, charmingly flirting with Paula in the guise of a wild beast. As Paula's attention is increasingly drawn to Julius, 
Stefan loses his patience and drops his freewheeling attitude, insisting in a rather bourgeois way on good table manners, cleanliness, and proper comportment. While this scene plays with masquerade and role reversal to highlight performative identities, it does so chiefly as a prelude to the broader lesson about business performance that Julius subsequently offers to Stefan.

For as Julius emphatically makes clear, conventional bourgeois masculinity will not fly in the era of business capitalism: 'You can't conform, that is deadly. [...] You have to understand that arrogance is the only thing that helps. You have to find your own work fantastic, or at least act like you do. Don't you get it? It's just a game.' In order to drive home the lesson that an unerring belief in one's performance of success will produce results, Julius locks Stefan to his desk and drills him in the discipline of becoming an optimized neoliberal subject, forcing him to cancel dates and obligations in order to work on his portfolio, and allowing him to stop working only to eat and to exercise. Indeed, the gambit pays off and Stefan finally lands a job at Krüger, a company that competes with Julius's firm. While laid-back Stefan had initially appeared to be the opposite of buttoned-up Julius, at the end of the film Paula tells her husband, 'Suddenly he became just like you', affirming the ascent of business masculinity as the new norm and illustrating the postfeminist message that, since all men are alike, one must embrace them just as they are. Indeed, as a successful employee, Stefan is now too tired to continue dating Paula, prompting her to accept the status quo and reunite with Julius when he returns home. At the same time, Stefan's newfound capital enables him to purchase a car, a luxury automobile that he refers to as 'showy, decadent, disgusting - simply the best!' His unbridled glee in consumerism signals Stefan's final turn away from the counterculture associated with 1968 and its eschewal of material possessions in favour of collective experience, and toward a wholehearted embrace of individualism and the pursuit of upward mobility.

Mobility and flexibility function as ambiguous signifiers in Männer, and the film charts how these qualities become firmly affixed to the neoliberal status quo, a trajectory that would later become characteristic of the Beziehungskomödie. A metaphor and nodal point for this ambiguity is the paternoster elevator at Julius's advertising firm, which also featured prominently in the publicity campaign for Dörrie's film. We learn that Paula first met Stefan in the paternoster, after coming to Julius's workplace to bring him a tie he had forgotten at home; the contrast between her tiewearing husband and the dishevelled artist within the space of business made Stefan especially attractive to her. Later, the paternoster is overtly 
connected to the mobility of gender and the flexibilization of labour, when the elevator forms a bridge between the diegetic final scene of the film and its well-known credit sequence.

Julius returns from his extended vacation to find a new atmosphere at the advertising firm. In contrast to the opening sequence of Männer, which portrays the workplace as a site of industrial capitalism with secretaries from the all-female typing pool responding to the male boss's advances, here Julius's suggestive remarks on a female colleague's dress elicit only a blank stare. As he steps on board the paternoster, he encounters the firm's CEO, who tells him that things have changed in his absence: the CEO has hired a promising young man away from the competition who will join Julius's department on the first of the month. When he protests that there is no opening in his department, the CEO tells him that in fact the new colleague will become the next creative director, replacing Julius himself. As the CEO tells Julius, 'You've become a bit unflexible recently', suggesting that the new colleague exhibits traits more befitting of the neoliberal workplace (the CEO himself appears to exemplify the style of the new creative class, proudly sporting a small ponytail and a loud tie covered in lightning bolts).

Exiting the paternoster, the CEO tells Julius he can meet the new colleague right away, who of course turns out to be Stefan. Previously positioned outside of the paternoster, panning up and down to follow the conversation between Julius and his boss, the camera is now repositioned inside the elevator, aligned with Julius's perspective as he first glimpses Stefan, before cutting back to a reverse shot as Julius attempts to hide from his former roommate, who is still in the dark about Julius's true identity. Then, in full frame, we see the illuminated green sign at the bottom of the paternoster's path, which reads in large block letters 'WENDEPUNKT - WEITERFAHRT - UNGEFÄHRLICH' (TURNING POINT - KEEP GOING - NO DANGER). This sign functions as a kind of epigraph for the ideological project of Männer, which renders harmless the transition to the new business capitalism.

Julius does keep going, and when the paternoster reaches ground level again, the CEO climbs aboard with an astonished Stefan in tow. As a crowd gathers, the two men - still riding the moving elevator - argue about Stefan's suitability for the job, as Julius takes ownership for everything from Stefan's arts training to the suit on his back. At first, the camera is aligned with the perspective of the CEO, who steps off the paternoster and watches the argument. We see him greet Paula, who arrives in the lobby and climbs aboard the elevator in order to bring Julius his forgotten tie, in a recap of her 
initial meeting with Stefan. Paula goes up in the elevator, but this time she encounters neither Julius nor Stefan, instead ascending from view and out of the film's narrative altogether. Meanwhile, first Stefan and then Julius begin to strip off their business attire. As they are revealed wearing nothing but underwear, a reverse angle exposes a tittering crowd of women taking in the spectacle of the two scantily clad men, whom we now see laughing and cracking jokes as the credits begin to roll.

In a film that is mostly unremarkable on a formal-aesthetic level, this sequence stands out for its inventive use of mise-en-scène and cinematography and for its play with the comedic convention of the sight gag, which condenses the film's thematization of masquerade, performativity, and exposure via the concealment and revelation produced through the mechanical motion of the paternoster (resembling the form of the film strip itself). Not only does Männer notably dispatch with the extraneous Paula in order finally to reunite the mobile subjects of business masculinity, Julius and Stefan, who strip together in the intimate space of the paternoster, but it also foregrounds the female gaze at their half-naked bodies through the diegetic audience of women viewers.

The paternoster forms a transition point between the final frames of the narrative and the credit sequence. Here, the camera holds on a long close-up of the moving elevator as the cast list unspools, before a cut shows the paternoster again in long shot. As the sequence continues, the credits now display the names of the film crew; at the same time, we see the actual members of the crew rolling by in the cabins of the elevator while holding items pertaining to their behind-the-scenes work (e.g. a camera and film cans for the cinematographers; recording equipment for the sound engineers; scissors for the editing team). In a sequence that brings into view the filmmaking process, women's film authorship is on particular display: we see women members of almost every creative team, concluding with the writer and director Doris Dörrie (dressed in boxing gear) and the film's co-producers Elvira Senft and Denyse Noever. Though Männer is notably devoid of women characters, this sequence centres the role of women as creators, demonstrating a certain reflexivity about the film's gender politics.

In fact, this reflexivity is on view at various points throughout the film, via its formal play with gendered forms of looking, not least in a series of episodes where the film cuts to Julius's subjective perspective as he spies on Paula and Stefan through a child's telescope, as well as in the overt positioning of Julius and Stefan as objects to be looked at (often in varying states of undress, including a full frontal nude shot of Stefan, still exceedingly rare 
for a man on film). However, this reflexivity about gender is also combined with deliberately sexist comments included in the dialogue between Stefan and Julius, comments that are played for laughs, contributing to the film's reception as a comedy willing to break taboos in the postfeminist age. Indicative of the omnivorousness of cinematic neoliberalism, Männer co-opts aspects of the feminist Frauenfilm, including attention to the politics of the gaze and a discourse of women's authorship, and redeploys them within the generic frame of the relationship comedy. For it is especially within the context of genre that the disorganized filmic language of Männer emerges most demonstrably.

In his compelling reading of German relationship comedies, Randall Halle draws an explicit link between economic neoliberalization and the comedy wave of the 1990s, in terms of both production contexts and narrative developments. As Halle points out, the shift to a profit-oriented funding model in West Germany in the 1980 s laid the groundwork for the emergence of the new, audience-friendly popular cinema that gave rise to the comedy wave (for which Halle explicitly cites Männer as a precursor film). At the same time, the neoliberal turn shaped characters and storylines focusing on the interplay of endemic precarity and cruel optimism, especially in the aftermath of German unification: 'In this new free market economy, many of the characters work part-time or are self-employed with little sense of security. Many of them place their hopes in the romantic spirit of capitalism, on the imagined financial windfall that will result when their talent is finally discovered. Women's economic conditions appear particularly precarious. ${ }^{18}$ In this regard, relationship comedies provide one of the key generic venues for promoting the neoliberal fantasy that ordinary people may become rich and famous via unusual or extraordinary paths. 'And yet', Halle goes on to point out, 'in all the films of the Comedy Wave these economic anxieties are displaced to low-level background concerns and do not provide the structure of the narrative. The characters seem to experience the same pressures as the films themselves'. ${ }^{19}$ Indeed, in what can perhaps be understood as a characteristic strategy of German cinema across film history, economic anxieties are displaced onto anxieties about sex and gender in relationship comedies.

Beginning with Männer, the films of the comedy wave share a specific late-2oth-century incarnation of this tradition: 'Their conventions derive precisely from a commonality of anxiety-humour based on a crisis of 
heterosexuality.20 Halle rightly draws a connection between Germany's decriminalization of same-sex sexuality in 1994 and the rise of the comedy production trend, which centred LGBTQ characters, especially gay men, often featuring a queer milieu and, as we will see in the case of Der bewegte Mann, a 'temporary-gay narrative'. ${ }^{21}$ If, in the conventional Hollywood screwball comedy, humour arises from a disruption within heterosexuality (the peril of choosing the wrong marriage partner), Halle argues that in German relationship comedies, humour ensues from the way queer elements destabilize heteronormativity, including queer characters and settings as well as improper desires (particularly gay men desiring straight men and vice versa). However, due not least to the marketization of cinema under neoliberalism, relationship comedies operate under the mandate of a 'happy ending', which seems to require the resolution of this disruption via the redirection of desire toward 'proper' objects, since 'the heterosexual male cannot both reciprocate the attraction [to the gay man] and remain heterosexual'. ${ }^{22}$ Halle's important analysis of the changed representation of gender melancholia under the new conditions of gay liberation and the removal of prohibitions on homosexuality emphasizes how the films reconfigure certain narrative conventions in order to achieve the required happy end. Notably, happy endings in comedy-wave films do not resolve the crisis of heterosexuality via the re-imposition of heteronormative behaviour. Rather, they offer individual solutions to individual problems by, in Halle's Freudian terms, 'fixing an individual ego-libido' to ensure that it is properly directed toward an appropriate object. ${ }^{23}$

As Halle's analysis suggests, these films focus on the individual, whose unmooring from traditional norms of gender and sexuality and traditional structures of family, employment, and social life they chart, offering a seismograph of the precaritization of life in neoliberalism. In the context of this precaritization, relationship comedies reconsider the traditional promise of the good life with its concomitant attachments to upward mobility, job security, and durable forms of intimacy, portraying the 'unbinding' of their characters from the fantasy that these ideals are mutually attainable and/or making visible the characters' obstinate refusal to relinquish such attachments. ${ }^{24}$ Flexibilized and precarious sexualities form the ground for 
these films' mapping of the present and their attention to how a discourse of individual choice and personal responsibility opens up new opportunities for non-normative intimate practices and affiliations that co-exist with traditional sexual identities and gender roles. In the case of Männer, we find an overt narrative about the connection between the dismantling of social solidarity, in the form of Stefan's communal apartment and hippie lifestyle, and the crisis of heterosexuality. While ostensibly occasioned by Paula's affair, this crisis is construed as one of the heteronormative family more broadly (completely unsurprised by their family's failure, one of Julius and Paula's children cynically points out at the outset of the film that 'No love lasts forever'.)

Following the model outlined by Halle, the main narrative of Männer focuses on the homosocial relationship and queer intimacy between Stefan and Julius that emerges from Paula's renunciation of her marital bond, but in the end, the status quo is reinforced when Paula and Julius reunite and Julius's ego-libido is directed back toward the proper heterosexual object. Notably, however, Stefan's desire is redirected away from both Julius and Paula and cathected not onto a more proper lover, but rather onto the pursuit of financial gain, evidencing the kind of effortless disbanding of affective ties in favour of self-optimized business masculinity that Woltersdorff describes: 'Unlike its predecessor Fordism, neo-liberalism allows for a flexibilization of sexual and gender norms, while it enforces the social narrative of competition and of profit-oriented selfishness'. ${ }^{25}$ Clearly exhibiting both of these tendencies, Männer does not end with Julius and Paula's reconciliation, but, as we have seen, instead reunites Julius and Stefan, leaving us with a symbolic image of gender and sexual mobility in the form of the two halfnaked men in the elevator. This ending is important, not because it subverts convention or points toward a new form of queer futurity, but rather insofar as it provides a template for the disorganized formal and generic language that would continue to characterize the German cinema of neoliberalism, and especially the immensely popular relationship comedies of the 199os. A woman's film about men that melds aspects of the feminist Frauenfilm with screwball conventions and draws its humour from an embrace of the mainstream, Männer piles on multiple endings in an effort to have it both (all?) ways. This disorganization of form and genre ultimately defies attempts to codify the comedy wave within received film theoretical paradigms, though it is certainly emblematic of the precarious times - for cinema, for sexuality, and for German society—out of which it emerged. 


\section{Intimacy between Men and the Failure of the Heteropatriarchal Family in Der bewegte Mann}

The nascent queerness of the intimacy between men on view in Männer is made explicit in Der bewegte Mann, the most popular German film of the 1990 s with more than 6.6 million tickets sold domestically. Based on the bestselling comic books by Ralf König Der bewegte Mann (The Moved Man, 1987) and Pretty Baby (1988), the film adaptation produced by Bernd Eichinger and directed by Sönke Wortmann follows the gay character Norbert (Joachim Król) who falls for the hetero Axel (Til Schweiger). The film's imaging of mobile and flexible sexualities is signalled already by the opening take, a swooping crane shot that moves fluidly through space, performing two 360-degree pans in opposite directions - a cinematic figure eight - while offering a birds-eye view of the crowd dancing in Cologne's Gloria Theatre to the strains of the Palast Orchester. Featuring singer Max Raabe, who plays a cameo in this scene, the Palast Orchester's retro soundtrack for Der bewegte Mann, a series of Schlager that are threaded throughout the film, evokes both a nostalgic return to the classical genre of the musical comedy and a period (the Weimar era) known for its gender and sexual mobility. The camera comes to rest on the hunky Axel, who works as a waiter at the theatre; a cut back to the dance floor reveals a woman who cranes her neck as she dances in order to get a better view of him. In a shot/countershot sequence typical for the romantic comedy-but performed here with inverted gender roles - the woman openly stares at Axel, so that he turns around to make sure she is looking at him and not at someone else standing behind him. Subsequently, the woman invites Axel into the bathroom, where they have sex in a stall. This opening sequence thus establishes Axel as the object of the gaze, a status he will occupy throughout the film as he becomes the focus of desire for (straight) female and (gay) male characters alike.

When Axel's girlfriend and co-worker Doro (Katja Riemann) discovers him having sex in the bathroom, she kicks him out of her apartment. Finding himself in need of a place to stay, Axel temporarily moves in with a new acquaintance, the gay man Norbert. Like Männer, Der bewegte Mann develops an odd-couple narrative about two unlikely roommates; as in the previous film too, the intimacy produced by living at close proximity creates a strong bond between the two men. In Der bewegte Mann, however, this intimacy is more overtly sexualized: in the 'temporary gay narrative' (Halle) the film develops, Axel not only participates avidly in the gay milieu that Norbert introduces him to, but he eventually exhibits a strong attraction to Norbert and, in an intimate scene that takes place in bed, almost has sex with him. 
If, as we have seen, German relationship comedies chart (and derive their humour from) the crisis of heterosexuality, in Der bewegte Mann this crisis develops from the attempt that Axel and Doro undertake to form a heteropatriarchal family, despite their mutual ambivalence about doing so. After she has kicked Axel out of the apartment, Doro discovers that she is pregnant with his baby. Chain smoking as she waits for a home pregnancy test, Doro pronounces the positive result a 'horror'. Though she agonizes over the decision to keep the baby, as a thirtysomething woman, she views the pregnancy as her only opportunity to pursue the normative route toward happiness via heterosexual marriage and childbearing, especially as she has been told by her doctor that having another abortion could harm her future reproductive health. While Axel would prefer to stay with Doro-after all, she provides for him economically and without her he is homeless-he appears to be constitutionally incapable of maintaining a monogamous relationship with her. Insofar as it displays the barriers that stand in the way of their mutual attempt to consolidate a heteronormative relationship (including Axel's promiscuous attraction to everyone but the pregnant Doro, his queer intimacy with Norbert, as well as Doro's own internalized homophobia, which leads to her repeated rejection of the 'temporarily gay' Axel), the film exhibits the destabilization of heterosexuality via queer elements in the ways that Halle identifies as characteristic of the genre. Although in the course of the film Axel and Doro get married and a baby is born, their ultimate failure to form a family underscores the precarity of traditional forms of relationality in the neoliberal age.

Der bewegte Mann makes visible along multiple vectors the coexistence of non-normative and conventional roles and practices that Woltersdorff identifies as characteristic of neoliberal sexualities. One of the film's running gags involves a men's consciousness-raising group consisting of heterosexuals who meet to discuss their sexual practices and critique their sexual fantasies in the ostensible attempt to become more tolerant and enlightened. The group's efforts range from inviting gay men to educate them about queer sexuality to discussing the specifics of vaginal vs. clitoral orgasm. Owing to their effort to develop more respect for women, they purport to abhor pornography, but on a trip to the local porn theatre, Axel catches one of the group's most solemn members, Klaus-Dieter, in the act of watching a sex film. Played for high humour, the men's group (which is comprised of an array of ridiculous-looking and -sounding characters, including one who speaks in an over-the-top regional dialect) satirizes politically-correct gender and sexual discourse, but it also places on display heterosexual men's ambivalent experience of navigating sexuality in the era after feminism 
and the consolidation of LGBTQ rights. In this way, Der bewegte Mann simultaneously offers an eye-winking acknowledgement of the integration and co-optation of sexual liberation in neoliberal societies and a rather melancholic narrativization of the precarity that has ensued.

The vacillation between these two stances forms a key horizon for the generic innovation of the relationship comedy. On the one hand, the characters in this genre experience a new mobility and fluidity regarding possible sexual partners, practices, and arrangements, but on the other hand they are unmoored from traditional structures and expectations in ways that prove disorienting. This is especially (though not exclusively) the case for the genre's heterosexual characters, while LGBTQ characters and milieus offer a kind of template for the emergent flexibilization of sexuality, a fact that helps to explain their persistent appearance in key roles in the films of the genre. As Woltersdorff argues, insofar as it is organized around the optimization of individual sexual pleasure and a spirit of sexual competition realized via commercial platforms 'the gay scene functions as a sort of forerunner in view of the development of markets of sexual exchange and serves as a transmitter of the market-like organization of sexual interests for the rest of society'. ${ }^{26}$ While this mainstreaming leads to the destigmatization of queer sexualities, it also has the effect of undoing the solidarity and political mobilization previously fostered by sexual minorities.

In the case of Der bewegte Mann, gay men mentor heterosexual men in the new, flexibilized forms of sexuality and masculinity. Norbert's friend Walter/Waltraud (Rufus Beck) educates the men's group in the exploration of anal eroticism, while Norbert himself trains Axel to be a better consumer, schools him in the domestic arts, and facilitates his career development as a photographer. While critics have viewed Der bewegte Mann as emblematic of West Germany's self-satisfied and provincial Wohlstandsgesellschaft (affluent society) ${ }^{27}$ — although the film debuted just four years after German unification, it exhibits virtually no trace of that epochal event - in fact neither Doro nor Axel, both of whom work in the service economy, is an avatar of the prosperous West. Rather, that position is occupied by the film's gays, especially Norbert, whose painstakingly maintained apartment, replete with well-laid breakfast table, carefully chosen décor, and the latest stereo equipment, is a testament to the new homonormativity, 'a privatized, depoliticized gay culture anchored in domesticity and consumption', captured by the film. ${ }^{28}$ 
To be sure, Norbert operates in the service of Axel's character development in ways that are consistent with the conventional portrayal of 'the gay friend', the stock character whose own evolution as a desiring subject is generally subordinated to that of the heterosexual protagonist. Here, the straight man Axel is unable to provide for himself, relying on women and gay men, who are tasked with maintaining structures of caregiving throughout the film. Its heroic positioning of the hapless straight man is matched by the film's rather misogynist depiction of female sexuality (pitting the Madonna-like Doro against the orgasmic Elke (Antonia Lang), who seduces Axel) and especially of pregnancy. Everyone in the film is horrified by pregnancy, the pregnant body, and birth, including Doro herself, Axel (who finds the thought of having sex with the pregnant Doro abhorrent), and Norbert, who is sickened by the blood and bodily fluids when he is compelled to attend Doro's birth. Der bewegte Mann certainly does not depart from the stereotypical and often retrograde depictions of gender and sexuality that, as we have seen in Chapter 2, are characteristic of Eichinger's producer's cinema more broadly.

Nonetheless, it is arguably Norbert and Axel's (rather than Doro and Axel's) relationship that this relationship comedy traces and dwells on, following the two men as they meet, move in together, break up, and reconnect in the end. The majority of the film's screen time is devoted to portraying Norbert and Axel together, and while the film permanently defers any visual depiction of the heterosexual couple having sex, the climactic sex scene of Der bewegte Mann gives us an extended view of the two men sharing a moment of queer intimacy in bed.

Axel and Norbert go to Doro's apartment to retrieve Axel's slide projector, which they find set up in Doro's bedroom. The two men lie down on Doro's bed and begin clicking through slides from a vacation that Doro and Axel took in the mountains. Norbert looks longingly at Axel, who appears to be absorbed in viewing images of Doro on screen, but who slowly lets his knee drop onto Norbert's leg (see Illustration 12). While he tries to call Norbert's attention to Doro's shapely figure on screen, Norbert (and the camera) dwell instead on Axel himself, who is wearing only a tank top. It is certainly no accident that this sex scene is triggered by scopophilic viewing, for the sequence humorously reflects on the way Der bewegte Mann redirects the gaze away from any conventional feminine object of to-be-looked-at-ness and toward Axel (and the actor who plays him, Til Schweiger, unrivalled as a sex symbol in post-unification German cinema), who is not only the main object of visual pleasure for characters within the film's diegesis, but also for audiences of the relationship comedy more broadly. As Christopher 


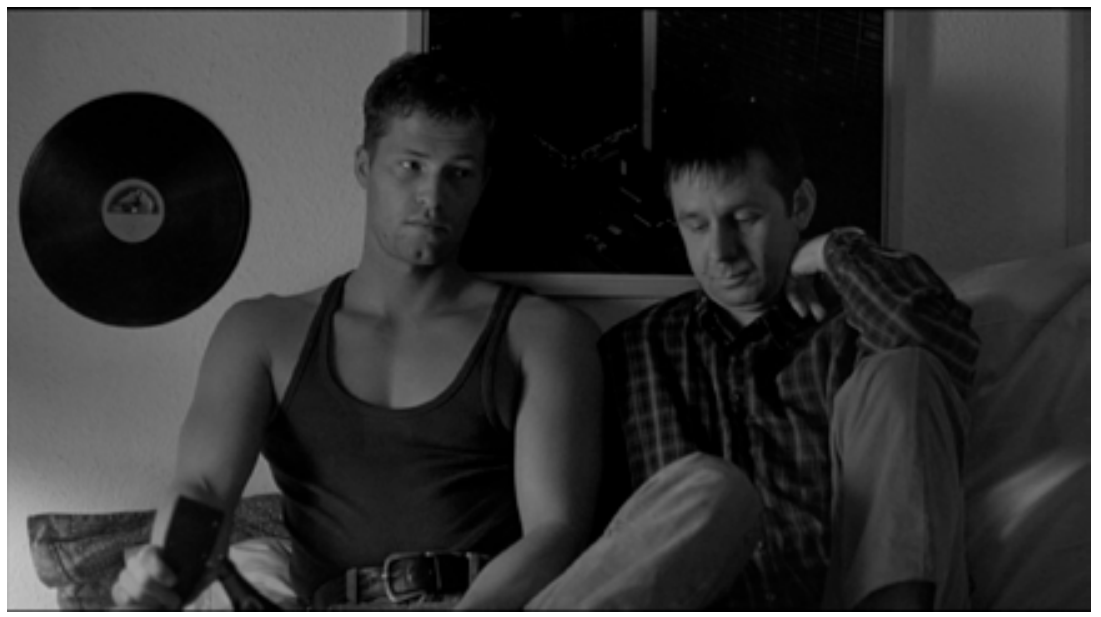

12. Queer intimacy: Axel (Til Schweiger) and Norbert (Joachim Król) in the climactic bed scene of Sönke Wortmann's Der bewegte Mann (Maybe...Maybe Not, 1994).

Treiblmayr puts it, 'While Doro hardly enters the camera's erotic field of vision, Til Schweiger's body constitutes an explicit erotic spectacle in the film, which is staged for both homosexual men and heterosexual women. The "classic" active/passive split between men and women observed by Mulvey and others is no longer in effect in Der bewegte Mann. ${ }^{29}$ Wryly noting that it is awfully hot in the apartment, Norbert begins to strip off his clothes, and soon he is wearing nothing but underwear. When a nude image of Axel appears on screen amidst the vacation photos, Norbert begins to kiss him on the shoulder, prompting Axel to comment rather nonchalantly, 'You took all your clothes off.' Then, Norbert disappears under the covers, presumably to perform oral sex on Axel.

At this precise moment, we hear the sound of a key in the lock, as Doro arrives home. Buttoning up his pants, Axel swiftly hides Norbert in Doro's wardrobe. Noticing that something is amiss, Doro begins looking for the woman she assumes Axel is hiding in the bedroom, instead finding Norbert, who comes out of the closet completely naked, a 'coming out' that is nonetheless drained of any symbolic valence in the normalizing context of the 1990 s portrayed by the film. Axel half-heartedly and rather dumbly tries to persuade Doro that he isn't gay (Axel: 'Every person is a little bit bisexual, we've known that at least since Einstein'; Doro: 'You mean Freud'), but Doro doesn't buy it: 'I'm completely baffled. We break up and after two weeks you're gay and I'm pregnant.' Doro's divulgence of her pregnancy to 
Axel here ostensibly precipitates the redirection of erotic energy toward 'proper' objects, since following this climactic scene, Axel and Doro reunite and subsequently marry, and Norbert begins a new relationship with Horst (Armin Rohde).

However, this redirection is not especially successful. Der bewegte Mann shows us neither the wedding (we see only a few shots on the steps of the church, where Waltraud and Fränzchen (Nico van der Knaap) show up in full drag with a reluctant Norbert in tow) nor the successful consummation of the marriage, since Axel proves unable to sleep with his pregnant wife. Likewise, the film's normalizing language positions Horst, a leather-wearing butcher who watches horror movies for breakfast, as an improper object for the mild-mannered vegetarian Norbert. When Axel attempts to reassert his heterosexuality by setting up a clandestine liaison (in Norbert's apartment no less) with Elke, a high school girlfriend who achieved her first orgasm with him, things go awry: after they take Bull Power, a hormone meant to boost sexual pleasure, Axel crouches naked on the coffee table believing himself to be a rooster, while Elke instead ends up having energetic sex in the bathtub with the gay butcher Horst.

This persistent 'misdirection' and mobility of desire endures into the final sequence of Der bewegte Mann, when Doro goes into labour and is accompanied to the hospital not by her husband but by Norbert (Axel is too high on Bull Power to realize what is happening). While this sequence stages a superficial resolution of the 'temporary gay' narrative-Norbert assures Doro that Axel is decidedly heterosexual and promises Axel that Doro will forgive him eventually for missing the birth-in fact the heteropatriarchal family is never successfully formed. Doro throws Axel out of her hospital room, refusing to speak to him, and it is Norbert who eventually introduces Axel to his infant son. As Axel scrutinizes him, the newborn suddenly morphs into a swaddled dog, ostensibly a humorous aftereffect of the bull hormone, but one that also puts a queer spin on the gaze of the father.

This surrealist dimension harkens back to an earlier dream sequence, in which Norbert envisioned himself pregnant with Axel's baby, eventually giving birth to a bird. Just after the climactic bed scene between the two men, a montage sequence shows us scenes of Norbert alone, pining for Axel; the passage of time is demonstrated by the changing seasons in the shots that comprise the sequence, which is accompanied by the Palast Orchester song 'Kein Schwein ruft mich an' (No one [literally: no swine] is calling me). Abruptly, the soundtrack shifts, and we see a shot of Norbert, in profile, wearing a maternity gown that stretches across his large pregnant belly. 
Norbert calls out, 'But Axel, you can't leave me alone in this condition!' Through a dissolve, Axel appears in the dream to tell Norbert that he's sorry but he's getting back together with Doro, before he fades out again. A cut shows us Waltraud and Fränzchen, both dressed as nurses, peering into the camera and asking: 'What's wrong, Norbert, are you going into labour?' Lying against a swirling red backdrop, Norbert grimaces in pain, as Waltraud urges, 'Norbert, you have to push, push now!' Finally, a cut reveals a hand holding a small parakeet, which closely resembles Axel's pet bird Schevardnadze. Waltraud proclaims, 'Such a strapping little lad!' and congratulates Norbert on the successful birth, as the little bird chirps like a newborn crying. Norbert's dream fantasy of giving birth to Axel's queer baby is subsequently mirrored by the final sequence, in which Axel envisions his baby as an adorable puppy, a (queer) fantasy offspring that he might share with Norbert in lieu of the biological infant he never quite claims from Doro.

At least since Halle's persuasive reading of the film, critics have tended to view Norbert as a facilitator of heterosexuality, whose role is to save the relationship between Doro and Axel. ${ }^{30}$ At the same time, as Treiblmayr acknowledges, the main intimate moments in Der bewegte Mann (albeit in a film that is not exactly noteworthy for its eroticism) take place between men. These include 'when Axel and Norbert lie in bed together during the "closet sequence" and in a later scene when they argue about whether Axel had an erection or not', ${ }^{31}$ as well as a kiss scene between two leather-clad men at the gay disco, shown in a tight close-up, which Treiblmayr views as especially noteworthy given the ongoing taboo in mainstream cinema-even in the 1990 - on depicting gay men kissing.

What is more, we never do see Axel and Doro (re)united in this relationship comedy's happy end. As in Männer, the female character simply disappears from view at the end of the film, which ultimately pictures Axel and Norbert leaving the hospital together, sharing a joke about the heritability of queerness (and the possibility that the baby might be gay). Treiblymayr reads in this ending a departure from the screwball conventions that have dominated the final third of the film and toward a new adaptation of the buddy movie, which codifies homosociality in a final movement away from male/female to male/male relationships. ${ }^{32}$ The film's final shot, included in the credit sequence, consolidates this homosociality by showing 
us Norbert, Axel, and Waltraud, now out of costume, singing in harmony to the Palast Orchester song 'Für einen richtigen Mann gibt es keinen Ersatz' (There's no substitute for a real man), a song that takes on rather campy connotations here.

As Halle argues, 'What makes the films of the Comedy Wave stand out in a history of sexuality is that they do not provide comfortable resolutions, and by no means does the crisis of heterosexual desire get resolved through the triumph of the heterocoital imperative'. ${ }^{33}$ I have suggested that this irresolution emerges not least from the genre's grappling with precarious sexualities in neoliberalism. Emblematic for the formally disorganized and ideologically promiscuous films of neoliberal cinema, Der bewegte Mann blurs conventions of gendering common to (heteronormative) romantic comedies in its depiction of the precarity of sexual and intimate relations after the breakdown of the traditional family. Ultimately, the film advocates for the neoliberal principle of individual freedom in sexual pursuits articulated by Axel early on in the narrative, when he tells Waltraud that he's not a homophobe because he believes that 'everyone should pursue happiness in his own way'. Axel's standpoint coincides with 'the emergence of a new aspect of modernization wherein tolerance of homosexuality has become a benchmark of social preparedness for admission into the transnational community', ${ }^{34}$ and the concomitant co-optation and depoliticization of LGBTQ movements in favour of nonredistributive forms of equality and integration into heteronormative institutions (e.g. marriage and the military). In this regard, the film simultaneously represents both a new stage in the normalization of cinematic depictions of LGBTQ characters and a form of mainstreaming that heralds the mandate for sexual minorities to conform to dominant culture. This nascent homonormativity is brought into sharp relief when we view Der bewegte Mann in parallel with Coming Out, a film produced during the same time period but arising from a very different context.

\section{Individual Happiness and the Precarity of Intimacy in Coming Out}

Taking place in Berlin on 9 November 1989, the premiere of Heiner Carow's Coming Out unexpectedly coincided with the fall of the Wall, but its contested realization as the first LGBTQ-themed feature film produced by DEFA 
also reflects the changing aesthetic and political constellations of the late GDR. Carow's film focused on the symbolic process of coming out not only to break the taboo on representing LGBTQ people in state-sanctioned East German culture, but also as a metaphor for the broader problem-reaching its apotheosis in late socialism-of how to reconcile the assertion of individual desire with the mandate for collectivity. However, as Katrin Sieg has put it: "The contradiction between the individual right to happiness and social reproduction staged by Coming Out could [...] no longer be resolved by the system at which this critique was aimed', since German unification and the obsolescence of the East German state quickly followed upon the film's debut. ${ }^{35}$

Coming Out narrates the story of Phillipp (Matthias Freihof), a young teacher who embarks on a heterosexual relationship with his colleague Tanja (Dagmar Manzel). When he runs into a former boyfriend, whom he had parted from as a teenager at the insistence of his parents, Phillipp experiences a reawakening of his disavowed attraction to men. On a secret visit to a gay bar, Phillipp encounters Matthias (Dirk Kummer), whom he eventually meets and sleeps with. Following a similar generic template to the relationship comedies discussed above, the narrative of Coming Out develops around this love triangle: Phillipp juggles his two lovers, neither of whom he tells about the other, until Tanja inevitably witnesses him in an intimate embrace with Matthias, and Phillipp is forced to choose.

Parallel to this conventional, invidualized 'love' story is the political narrative pursued by Coming Out, which depicts Phillipp's socialization as a gay man-his coming out process-in the context of East Berlin's gay subculture and in defiance of the internalized homophobia of the GDR mainstream, for which the women in the film (Tanja, the director of the school where he works, and his mother) serve as the mouthpiece. As commentators on the film have pointed out, Phillipp experiences his gayness as incompatible with socialism, exposing to viewers the assumed heterosexuality of the collective subject in the GDR. ${ }^{6}$ Genre forms a necessary horizon for this exposure, as Coming Out relies on the conventional generic structure of the relationship film to orient spectators within a familiar plot scheme and secure sympathy for the film's protagonists in order to then demonstrate the harm perpetuated by precisely these normative conventions.

Though not a comedy, Coming Out depicts the crisis of the heteropatriarchal family and the destabilization of heteronormativity via queer elements; 
it also marks the becoming visible of gay characters in East German narrative cinema. In both regards, the film occupies a similar status to the West German relationship comedies discussed above. Indeed, Coming Out offers a plea for the acceptance and toleration of same-sex desire in ways that sometimes run parallel to the Western discourse of individualism developed in Der bewegte Mann, encapsulated by Axel's disavowal of homophobia because 'everyone should pursue happiness in his own way'. At the same time, though, by virtue of its production in the late GDR, Coming Out comprises a unique document of a (film) historical moment foreclosed upon by subsequent events, and in this regard it also preserves a different vision of cinema and sexuality than the one offered by West German films of the period.

The path toward LGBTQ representation and emancipation charted by Coming Out was subsequently forestalled upon not only by the dismantling of both DEFA and the GDR itself, but also by the concomitant end of the nascent East German gay and lesbian movement as well as the emergence of the HIV/AIDS pandemic in the former eastern states. The undoing of the East German gay and lesbian movement marked the termination of the attempt to create an alternative to the 'commercial ghettoization' of queer culture associated with the West ${ }^{37}$, while the threat of HIV/AIDS signalled the decline of an erotic culture of public, unprotected sex between men (the latter notably on view in a key scene of Coming Out, which I will return to below). Both of these events thus figure in the dismantling of collectivity and the individualization and privatization of (gay) life associated with neoliberalism.

In this regard, Coming Out constitutes a significant archive of disappearing pasts and emergent futures. As David Brandon Dennis argues, 'The film is significant both historically and artistically because it captured the unique moment in East German history when "third ways" seemed desirable and possible, criticizing what was and imagining anew what life could be in the GDR'. ${ }^{8}$ In somewhat different terms, Kyle Frackman emphasizes the queer utopianism of Coming Out, arguing that, like José Estaban Muñoz's conception of queerness as 'essentially about the rejection of a here and now and an insistence on potentiality or concrete possibility for another world', Carow's film also 'examines the present through its deployment of elements from the past in order to project a possible future'. ${ }^{39}$ Both Dennis

37 See Soukop, ed., Die DDR. Die Schwulen. Der Aufbruch, 113, qtd. in Dennis, 'Coming Out into Socialism'.

$3^{8}$ Dennis, 'Coming Out into Socialism.'

39 Frackman, 'The East German Film 'Coming Out' (1989)', 458-459. 
and Frackman identify the sense in which Coming Out occupies a liminal space between a socialist past that it critiques and aims to refigure and the neoliberal future that ultimately came to pass.

In aesthetic terms, Coming Out reflects the realist cinematic language that predominated at DEFA and is shaped by an agenda of public enlightenment about the previously taboo subject of homosexuality. Notably, however, while advocating for acceptance and toleration of LGBTQ people, Coming Out also resists the mandate to valourize queer communities through 'positive' (homonormative) images that increasingly characterized the transnational project of queer cinema under the sign of gay liberation in the West beginning in the $1980 \mathrm{os}$. Rather, via its interrogation of the contradiction between the individual pursuit of happiness and the social reproduction of the collective, the film considers alternative forms of relationality and community, while also developing a de-idealized depiction of masculinity that dovetails with its anti-patriarchal critique of the heteronormative family. While a comparison to the West German relationship comedies thus helps to establish how Coming Out archives the neoliberal transition and documents the failing family, the film's aesthetic form and its imaginary differ significantly from those of Dörrie and Wortmann. Instead, Carow's film anticipates and resonates with representations of intimacy, erotics, and the material world in anti-identitarian forms of political film and media emerging in the context of the Berlin School and contemporary feminism, a connection I will elaborate in the final section of this chapter.

Coming Out begins with a prologue that introduces the stakes of the film's representation of homosexuality in the GDR. It is New Year's Eve and fireworks explode over East Berlin. Amidst the noise emerges the siren of an ambulance rushing Matthias to the hospital after a suicide attempt. In a scene highly reminiscent of the overdose sequence in Solo Sunny (see Chapter 3) and which similarly indexes the conflict between individual self-determination and managed collectivity, here we see a team of women doctors threading a tube down Matthias's throat and forcibly pumping his stomach. Shot in an actual clinic in Berlin and featuring real doctors, this extremely realistic scene conveys with immediacy and candour the shame and trauma that have driven Matthias's suicide attempt. As he recovers in the clinic hallway, a doctor asks him why he overdosed, and, in tears, he replies, 'Because I'm gay - I'm homosexual'.

This image of Matthias's anguish is counterposed by our first glimpse of Phillipp, who is introduced riding a bicycle through the streets of the city. In contrast to static close-ups of Matthias in the harshly lit interior of the clinic, we see Phillipp in long shot, moving through sunny exterior spaces; 
the association of Phillipp with mobility, light (and indeed enlightenment) is affirmed as he arrives at the school where he teaches and writes his name on the chalkboard: Klarmann (literally: man of clarity). After the introduction of Phillipp, the first third of Coming Out initially appears to be unrelated to the prologue, as it follows the conventions of the traditional romance. In a classic meet-cute, Phillipp accidentally bumps into fellow teacher Tanja in the school hallway, and though she is at first annoyed by the bloody nose she receives in the mishap-foreshadowing the ultimate injuriousness of the relationship that ensues - the two spend the evening drinking and dancing together, ending up in Tanja's bed at her initiative.

Here and in several subsequent scenes depicting Tanja and Phillipp in bed together, she is fully clothed while he is naked, the object of her (and our) gaze. In one sequence, Tanja even sits in bed eating pickles from a jar while ogling Phillipp as he lies nude before her. Phillipp's positioning as a sex object on display is underscored when Tanja invites her former neighbour, nicknamed Redford because of his blonde locks, to come over and inspect her new boyfriend. However, when Redford arrives, he turns out to be Jacob (Axel Wandtke), an old acquaintance of Phillipp's. Unsettled by his arrival, Phillipp is unfriendly, even hostile, toward the other man. Beginning to sweat, he leaves the room to rinse his face off under the shower head; as he shakes off the water, Phillipp becomes entangled in the lingerie hung up to dry there, in a symbolic shot that portrays the messy situation his intimacy with Tanja has created for Phillipp.

As we subsequently learn, Jacob and Phillipp shared a relationship as young men, until Phillipp's parents - aiming to prevent their son from expressing his sexuality_blackmailed Jacob into leaving Phillipp by buying him a bicycle and a compass. Subsequently, Phillipp has apparently conformed to their wishes by living as a straight man, but his encounter with Jacob exposes the lie, and Phillipp now begins to explore his repressed queer desire. Visiting a gay bar, Phillipp encounters not only a diverse clientele and a colourful night life that contrasts sharply with the staid world of Tanja's flat and the overall greyness of East Berlin, but also a sphere of sociability and relationality - a form of collectivity based on affinity rather than familial ties or the mandate for biological and social reproduction-that opens up a new world to him.

While the film's previous thirty minutes have told the story of Phillipp and Tanja's romance through largely conventional cinematography, editing, and framing familiar from domestic melodramas, with an understated soundtrack, the gay bar scene marks an abrupt shift in the filmic language of Coming Out. Rapid editing, mobile camera, and a pop soundtrack featuring 
Frank Schöbel's 1971 Schlager hit 'Gold in deinen Augen' portray a vivid mise-en-scène of drag performers in flamboyant costumes, men kissing, and an array of body parts on display. Shot on location in an actual gay bar, the Schoppenstube in Prenzlauer Berg, this and later scenes feature authentic figures from the East German queer scene including most notably the well-known trans personality and founder of Berlin's Gründerzeit Museum, Charlotte von Mahlsdorf. The documentary quality of these sequences is crucial for the political enterprise of Coming Out, to make visible the reality of LGBTQ life which had previously remained hidden and taboo in the GDR.

Within the context of the film's narrative, this reality at first appears frightening to Phillipp, since it seems to entail the renunciation of social norms in favour of precarious intimacies. However, the central sequence of the film, in which Phillipp moves out of bed with Tanja and into bed with Matthias, unsettles the alignment of hetero/homo with stable/precarious forms of intimacy, ultimately placing into question received conceptions of intimacy and relationality altogether. At the start of this sequence, Phillipp suggests going out, expressing his dissatisfaction with the domestic routine he and Tanja have established, but she rejects his suggestion since she is tired. We see Phillipp in bed, reading aloud to the dozing Tanja, but soon he arises from bed, turns out the lights, and eventually leaves the apartment, following Matthias's earlier invitation to attend his birthday party taking place that evening. At the gay bar where Matthias and Phillipp first met, a large table has been set up, around which Matthias's entire family sits, celebrating with coffee and cake; the presence of his parents demonstrates that, in contrast to Phillipp, Matthias-whom we first encountered in the film's prologue having attempted suicide - has now successfully navigated the process of coming out and is able to live openly and be accepted by his social circle as a gay man.

A cut from the bar takes us to the interior space of Phillipp's apartment, where he and Matthias touch and kiss. Hesitantly, Phillipp asks Matthias, 'Don't you want a family? To have kids some day?' While Phillipp continues to express reticence about breaking from heteronormative expectations regarding family and reproduction, Matthias demurs, acknowledging that he doesn't want any of that, since he also knows it isn't in the cards for him. Instead, Matthias begins reciting his grandmother's erotic poetry, a recitation which demonstrates intergenerational affinities, placing Matthias within an alternative family genealogy of flouting normative expectations regarding sexuality, while also humorously breaking the ice with Phillipp.

The two men begin to undress, and in extended takes, we view them naked, intertwined in bed, tenderly embracing, caressing, and kissing one 


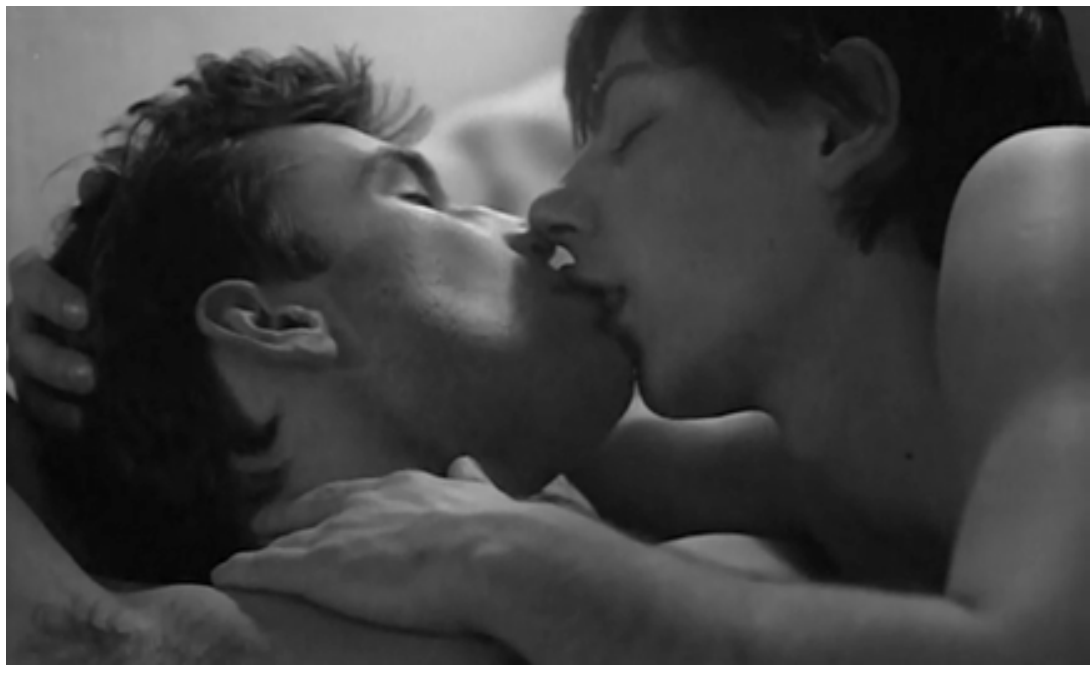

13. Naturalizing queer eroticism: The sex scene between Phillipp (Matthias Freihof) and Matthias (Dirk Kummer) in Heiner Carow's Coming Out (1989).

another (see Illustration 13). The open eroticism of this sex scene contrasts sharply with the depiction of Phillipp's intimacy with Tanja-Tanja is always clothed, Tanja and Phillipp's kisses are forced, and we never see the couple embracing in bed-and this contrast serves to naturalize the depiction of gay sex in Coming Out. As Dennis puts it, 'This is the first real love scene of the film; those between Phillipp and Tanja show little or no actual intimacy. [...] The message leaves little doubt as to its significance: socialist morality does not require, and should not entail, the valourization of heterosexual reproduction..$^{40}$ While this sequence is indeed pivotal to the film's didactic goal of inculcating acceptance of LGBTQ people in the GDR, its strategy of doing so by naturalizing queer eroticism differs substantially from that of West German films of the period that pursued a similar agenda of acceptance via slapstick comedy, encapsulated by the bed scene in Der bewegte Mann. If the latter film, as Treiblmayr observed, was remarkable for its violation of the taboo on gay male sexual expression in mainstream western cinema of the 1990s, Coming Out presents a much more frank depiction of gay sex, and one that is even more notable given the dearth of visual representations of queer sexuality of any kind in prior mainstream East German culture.

Still, as a film that makes an explicit didactic address to a presumptively heterosexual audience inured to the open homophobia of the GDR, Coming 
Out continues to rely on the convention of the love triangle when exploring the barriers to coming out experienced by Phillipp. Indeed, his encounter with Matthias, his first time having sex with a man, is redirected when Phillipp returns to Tanja after learning from a school colleague that she may be pregnant. Again like Der bewegte Mann, Coming Out engages conventional genre expectations familiar from the relationship film to connect intimacy between men with the crisis of heterosexuality and the failure of the family.

However, by developing an intersectional critique of real-existing socialism's heteronormativity, Coming Out ultimately makes clear that the crisis of the heteropatriarchal family comes from within patriarchy rather than from the 'threat' of queerness. ${ }^{4^{1}}$ Phillipp briefly returns to Tanja, promising that he won't abandon her while she is pregnant. We see him washing the dishes in her kitchen, emphasizing Phillipp's cognizance of the double burden that accrues to women in the GDR, a topic that Phillipp's mother also discusses with him on several occasions throughout the film. We first see his mother, a writer who labours at a typewriter over which hangs a large poster of Bertolt Brecht, asleep at her desk, and when he awakens her, she exhorts him to help her out with the housework. Here, Phillipp vocally recognizes that his mother has been unfairly burdened with reproductive labour, since his father does not participate in caring for the children or the household. Phillipp's critical awareness of women's second shift clearly drives his reluctance to split up with Tanja. Nonetheless, their relationship, already in turmoil, reaches its climactic breaking point when the love triangle is finally exposed.

At a public concert, Phillipp and Matthias find one another during intermission, and Tanja witnesses their intimate embrace. When Phillipp introduces her to Matthias as his wife, Matthias finally grasps the reason for Phillipp's distance, just as Tanja understands the truth of Phillipp's betrayal. Subsequently, Phillipp loses both lovers. He never reunites with Tanja, who disappears from the narrative altogether, and the fact that we never learn the outcome of her potential pregnancy underscores the failure of the family in Coming Out. Although he searches for Matthias in hopes of reuniting with him, when Phillipp ultimately finds him, Matthias has a new boyfriend, Phillipp's student Lutz.

In line with its broader social critique, Coming Out offers neither a resolution to Phillipp's coming-out process nor a happy ending to the love triangle that drives the narrative, instead reiterating the contradiction

41 For an extended discussion of the way the political critique of Coming Out engages with East German feminism, see Sieg, 'Homosexualität und Dissidenz.' 
between individual desire and managed collectivity figured by Phillipp's story. However, its critical portrayal of the social contradictions that prevent Phillipp's realization of individual happiness within the confines of a normative relationship underpin both the film's focus on interlocking forms of oppression and the way it opens onto alternative forms of relationality.

In order to demonstrate the linkages among struggles to end class-, sex-, and race-based oppression, linkages that the film posits as integral to the political ideals of socialism, Coming Out correlates the Nazi persecution of both Communists and gays with the anti-Black racism and homophobic violence perpetrated by neo-Nazis in the GDR. Crucial to the development of this intersectional critique is another relationship: When Phillipp first visits the gay bar, he encounters not only Matthias, but also the older man Walter (Werner Dissel), who welcomes and encourages him. Phillipp drinks to excess, and Walter and Matthias together escort him home and make sure he is safely in bed. If Matthias, whom we first encounter dressed in a Pierrot costume and wearing a full face of make-up, is associated with the contemporary gay subculture that flourishes in alternative social spaces like the bar, Walter facilitates a historical perspective on queer sociability and relationality. As we have scene, Phillipp embarks on a conflicted relationship with Matthias, but the film does not end by resolving this conflict and uniting the couple; instead, it is intergenerational solidarity with Walter that ultimately plays a pivotal role in Phillipp's coming out.

In the film's penultimate scene, Walter tells the younger man about his experience as a soldier in the second World War, when he and his male lover were exposed by the Nazis, forced to wear the pink triangle, and deported to Sachsenhausen, where his lover was murdered. Articulating in a nutshell the political critique of Coming Out, Walter tells Phillipp, 'We worked like crazy. We stopped mankind's exploitation by mankind, now it does not matter if the person you work with is a Jew, or whatever. Except the gays, we forgot them somehow.' However, while Walter's statement highlights the inconsistency of a socialist ideology that has ostensibly succeeded in the fight against fascism while continuing to perpetuate homophobia, the film has already given lie to this account of socialism's triumph against exploitation by foregrounding the prevalence of neo-fascism in the GDR in ways that complicate identity categories, particularly for Phillipp.

In an early sequence, Phillipp is returning home from the opera with his students when they witness a group of skinheads attacking a Black man on the train (actor and director Pierre Sanoussi-Bliss in his first film role). Phillipp intervenes, getting a black eye and a bloody nose in the process. As he throws the skinheads off the train, the camera dwells on the station 
sign, 'Marx-Engels-Platz', emphasizing the contradiction between socialism's emancipatory claims and the reality of everyday racism in the GDR. Later, Phillipp witnesses another attack by neo-Nazis, this one directed against a queer white person in the subway passage at Alexanderplatz, but this time he runs away rather than intervening. These parallel sequences establish a correlation between racist and homophobic violence; at the same time, the disparity between Phillipp's active response to racism and his flight from homophobia suggests, in Bradley Boovy's words 'the ways in which bodies of colour have long been made to do labour in the creation of white Western subjects', ${ }^{22}$ including the formation of gay male subjectivity. As Boovy's work demonstrates, same-sex attraction has historically been racialized as white in the German context, a point that is made visible and also complicated to some degree in Coming Out.

Phillipp initially runs from the violent scene in the subway passage, identifying with rather than defending the victim, and therefore seeking to escape the danger attached to public displays of queer eroticism and intimacy. However, soon thereafter, he sets out for the well-known gay cruising area in the Volkspark Friedrichshain, which the film depicts in a detailed scene that demonstrates the impersonal and ambient forms of intimacy pursued by men who meet in the dark spaces of the park and retreat to the pissoir or the bushes to have sex. Here, Phillipp rejects one man and then accepts a sexual encounter with another man. One of the few commentators on the film to explicitly discuss its representation of cruising, Dennis writes that 'The gloomy park and dimly lit faces cast a colder, anonymous, and impersonal shadow on the subculture. Although the man he picks up in the park looks like Matthias, the sex they have is casual and emotionally unfulfilling.' ${ }^{43}$ To be sure, the cool lighting scheme and the medium and long shots in this sequence underscore anonymity in ways that contrast strongly with the warm colours of the gay bar and the close-ups deployed in the film's earlier sex scenes. However, it is this cruising sequence that initiates Phillipp into a form of erotic encounter and queer relationality that differs substantially from the directed and reciprocal relationships he pursues with both Tanja and Matthias, and which ultimately signals an opening toward a form of communal alterity beyond the boundaries of identitarian community. As Dennis points out, 'The last scene in the bar, which features Phillipp's confrontation with Walter, styles the flamboyant cheerfulness of the subculture as a farcical 
performance. ${ }^{44}$ When Phillipp first returns to the bar, he drunkenly flails around in a physical presentation that enacts his failure or refusal to accede to the norms even of this subculture. When the host threatens to throw him out, however, Walter joins Phillipp in drinking to excess, ordering an entire tray of brandies, which he proceeds to down one by one as he tells the story of his persecution by the Nazis. Excessive drinking - a common trope of refusal in DEFA films, as we have seen in the case of Solo Sunny-here figures a form of sociability in defiance of the twin alternatives available to Phillipp, participation in the subculture (implying resignation from the broader quest for collective solidarity within socialism) and homonormative coupledom. This defiant sociability instead positions the intergenerational 'odd couple' Walter and Phillipp as 'affect aliens', who, in Sara Ahmed's terms, refuse the promise of happiness as a coercive form of politics that constructs a normative horizon of expectation predicated on accruing the right elements (marriage, family, career).

Indeed, the final sequence of Coming Out notably depicts Phillipp defying this normative horizon once more, this time in the context of his classroom, where he is subjected to an unannounced observation by the school administration after he is outed at work. Refusing to teach his class in the face of this surveillance, Phillipp turns away and looks out the window, as the camera follows his gaze across the littered schoolyard and the audiotrack unspools only discomfiting silence. Increasingly perturbed by Phillipp's antisocial and non-productive behavior, the school director shouts his name, 'Kollege Klarmann!', and Phillipp, looking directly into the camera, replies only, 'Ja'. The blurred affects represented in and triggered by this scene, which combines refusal with affirmation, insecurity with avowal, suggest an opening onto new imaginaries, forms of communal alterity not captured by the available models of collectivity represented in the film. The irresolution suggested here is underscored in the film's final scene, which comes full circle by showing Phillipp cycling once more through the traffic of East Berlin, in a reprisal of the opening shots of Coming Out. The circularity and ambiguity of this ending reiterate the central dilemma posed by the film, making visible once more the precariousness that ensues from the tension between collectivity and individuality. Here Phillipp's mobility is left open to interpretation: Is he caught within a circuit defined by homophobia, one that cannot be broken without social change, or does his movement suggest a new measure of self-determination in forging a path toward individual happiness? In hindsight, the ending of Coming Out 
appears perhaps even more radically open than it did in 1989 , given that the framing of this irresolution no longer obtained just months after the film's premiere.

\section{Disorganizing Genre in Sehnsucht}

Offering a close observation of rural life in the former East Germany fifteen years after unification, Sehnsucht tells the story of a love triangle that develops when locksmith and volunteer firefighter Markus (Andreas Müller) leaves his wife and childhood sweetheart, homemaker Ella (Ilka Welz), for the weekend to attend a fire brigade training in another village, where he begins an affair with the waitress Rose (Anett Dornbusch). Set in the present day, the village and the characters in Sehnsucht are caught between a quickly receding past and an uncertain future; the film depicts the nascent impact of intensifying neoliberalization on ordinary life and intimate relationships in a context where traditional culture is disintegrating, creating an increased sense of disorientation. This disorientation is figured both by the film's form - which escalates the viewer's discomfort through a combination of smash cuts that detract from our comprehension of events taking place on screen and long takes portraying awkward or uncomfortable behaviourand by its approach to genre. Sehnsucht draws on traditions of German narrative, including the fairy tale and the Heimatfilm, but its protagonists also dance to Europop hits, creating a mash-up of old and new, traditional and contemporary culture befitting of the disorienting times it depicts. The film's epilogue, which takes place at a temporal remove from the diegetic narrative, offers both a metacinematic reflection on storytelling, focusing on the figure of the female narrator, and an explicit invitation to attend to the operations of genre, as we witness teenagers on a playground discussing whether they find the events narrated by the film tragic, comic, or romantic.

Although the crisis of heterosexuality depicted by Sehnsucht does not emerge in tandem with homosociality or queerness, its narrative proceeds along similar lines to the other films discussed in this chapter, portraying the unmooring of characters from traditional norms of gender and sexuality and the precariousness that results, especially for the male protagonist Markus. As its title suggests, Sehnsucht is a film that takes affect as its central theme: Markus, Ella, and Rose struggle to reconcile traditional village life with contemporary reality, and they all seek and fail to attach their longing to an appropriate object, a failure that is not resolved by the film's open ending. While Sehnsucht both invokes and offers metacommentary on the 
relationship comedy, its aesthetic vocabulary resonates strongly with the cinematic legacy of DEFA.

As director Grisebach has acknowledged, 'that very unique mixture of realism and fairy-tale world, which was quite believable' captured her imagination as a child in West Berlin, where she regularly saw DEFA films on television; while she cites their influence on her own filmmaking as rather indirect, Grisebach's description of their approach helps to capture the resonance the legacy of East German cinema finds in Sehnsucht: 'What continually impresses me about DEFA films is their cognizance of diverse milieus and figures. It has a lot to do with establishing proximity, with taking their subjects seriously, as well as with trusting the substance of "reality." Therein lies for me a kind of appeal, a lead to follow'. ${ }^{45}$ Indeed, Sehnsucht follows this lead both thematically and formally, through its focus on ordinary lives and average settings and its commitment to realism. As Leila Mukhida succinctly describes it, "The result is a portrait of the kind of local, former East German working-class community that is largely absent from the landscape of contemporary German film. ${ }^{46}$ While it is indubitably a fiction film, in both style and substance Sehnsucht stands at the intersection of documentary and feature filmmaking: it began as a video documentation about the lives of thirty-something Germans, for which Grisebach conducted over 200 interviews in Berlin and Brandenburg during a fellowship from the DEFA Foundation to investigate the life and people of the area. Deriving from this original documentation, Sehnsucht was shot on $16 \mathrm{~mm}$ film and features lay actors whom Grisebach approached at shopping malls and fire brigade picnics, including actual inhabitants of Zühlen, the tiny village that provides the film's setting. These authentic features of its form, along with its observational style of cinematography (by Bernhard Keller) - often using a handheld camera, set up either very close or quite far from the characters, and regularly employing long takes - as well as its foregrounding of ambient sound, lend the film an ethnographic quality.

Like Coming Out, Sehnsucht archives a form of life that is disappearing due to modernization and the undoing of collectivity, an aspect of the film that also overlaps with its resignification of the Heimatfilm genre. While it shifts focus onto intimate relationships in the rural countryside (where the effects of globalization and neoliberalization following unification are less overt than in Berlin), Sehnsucht shares with Coming Out a critical interrogation of the heteropatriarchal family and masculinity, as 
well as an exploration of changed forms of intimacy in a storyline where traditional and flexible family structures and gender and sexual norms quite literally collide. Grisebach's film also eschews closure in ways that place into question both established filmic conventions and received forms of relationality.

Sehnsucht begins, in medias res, with the depiction of an unsettling incursion into the village landscape, the car crash of an urban couple who had been travelling at high speed along the rural road. The very first shot presents an extreme close-up of Markus that gives us no information about what is happening except what we can read on his impassive face; it is only when the camera cuts away to a medium shot that we discern this to be the scene of a crash and see that Markus is tending to an injured body. The digressive presentation of the crash via a series of indeterminate shots, which the viewer must piece together to make sense of, alerts us already at the outset to the formal demands the film places on viewers, while also approximating on an affective level the disconcerting quality of this violent incident for the village's inhabitants. A siren sounds, and we see two long shots of children biking and a group of people walking across a field, presumably toward the scene of the accident. Subsequently, three discrete shots present different angles on a car that has smashed up against a large tree. Markus's monosyllabic answers to a police officer who interviews him offer scant information about what has transpired. However, in a scene that will later be mirrored by the epilogue, we hear a group of first responders speculating on the cause of the accident and learn that the couple, who were not wearing seatbelts, likely drove into the tree intentionally, in an apparent suicide pact.

Mukhida argues that Sehnsucht 'seeks to heighten viewers' sensitivity toward violent acts in moving images ${ }^{47}$ through the use of an observational camera and an 'unromantic aesthetic' that eschews both stylization and graphic depictions while also foreclosing upon both a voyeuristic pleasure in looking and the possibility of identification with the victims of the violent events it represents. Likewise, Marco Abel argues that Grisebach's 'aesthetic mode of encounter with German reality [...] simultaneously invokes the register of representational realism and its attendant truth-claims, and affectively intensifies this register to such a degree that our perception of the reality (and truth) it seemingly represents is put at stake. ${ }^{8}$ The aim of this aesthetic mode is, in Grisebach's own words, 'a sharpening of our 
regard' for the everyday. ${ }^{49}$ As both Mukhida and Abel suggest, Grisebach's formal intervention takes on a political and ethical dimension insofar as it places dominant forms of cinematic representation into question and sensitizes viewers to reality, in particular forms of violence that permeate ordinary life at present. With its focus on self-inflicted violence (as depicted in the suicide attempts that bookend the film) as well as on subtle forms of intimate violence, as in the bed scene discussed below, Sehnsucht emphasizes the violent incursions posed by neoliberalization, even if this process of socioeconomic transformation is portrayed digressively rather than head on. Importantly, violence in Sehnsucht is always yoked to intimate relationships, and the use of observational cinematography and a dispassionate aesthetic sharpen our regard for the latter as well as the former.

As the first person to arrive on the scene of the car crash, Markus is especially troubled by the interconnection of violence and intimacy figured by the double suicide pact, which presents itself as the force behind his subsequent aberrant behaviour. Markus tells his wife Ella that he feels as though he had played the role of fate, since he inadvertently derailed the couple's plans to die together by saving the man's life. Ella replies with her own interpretation of the event: 'Although it's really horrible, it's also terribly romantic', and her mention of Romeo and Juliet both frames and foreshadows her own tragic love story to follow. As they speak, Markus and Ella sit at the kitchen table in their modest house, whose anachronistic interior spaces form the staging ground for their intimacy. 'I would do anything for you', Markus says, before a cut shows the couple in bed, sleeping in a tight embrace, as the dawn light filters in through the windows. This image of Markus and Ella as representatives of white, working-class, heterosexual intimacy-the most conventional sort of normative relationship-seems to be affirmed by the subsequent sequence that depicts a traditional family dinner, where three generations sit around the kitchen table telling funny stories, and Markus and Ella's affectionate relationship with their nephew suggests their desire for children of their own. However, Sehnsucht goes on to depict not the consolidation but rather the crumbling of this normative horizon, tracing the failure of the prospective family Markus and Ella never form.

Following the family dinner, Ella plays 'Eisbär' on the electric piano, while Markus, wearing a toy tiara, looks on. A classic of the Neue Deutsche Welle first released by the Swiss band Grauzone in 1980, 'Eisbär' features a short lyric, repeated again and again: 'Ich möchte ein Eisbär sein/ im kalten Polar/ Dann müsste ich nicht mehr schrein/ Alles wär so klar' (I 
want to be a polar bear/ In the cold Arctic air/ Then I wouldn't have to cry/ Everything would be so clear). The song's melancholy lyrics are a harbinger of the film's subsequent events, but 'Eisbär' also marks the incursion of global pop culture into the traditional village life of eastern Germany. Like the other pop songs that feature prominently in the film, the inclusion of 'Eisbär' ironically highlights the old-fashioned lifestyle of Zühlen's inhabitants while also foreshadowing the untenability of their mode of life. At the same time, 'Eisbär' figures the affective horizon of Sehnsucht - the unsettled and blurred feelings that cause the characters to experience the eponymous 'longing' of the film's title-an inchoate desire for clarity and simplicity of emotion in the face of changing norms and expectations.

In depicting the longing unleashed by the clash of old and new, Sehnsucht draws on and resignifies the unique German genre of the Heimatfilm, one of the key sites for addressing this clash within the context of German culture. $5^{\circ}$ Conventional Heimatfilme from the heyday of the genre in the 1930s-1950s 'depict a world in which traditional values prevail: love triumphs over social and economic barriers, and the story is usually set in an idyllic German countryside, highlighting maypoles and other folkloric traditions'.51 As Johannes von Moltke has argued, the genre's ongoing omnipresence in German audiovisual culture can be attributed to its ability to provide 'very flexible imaginary solutions' to ongoing social problems, especially regarding 'the transformations of space brought about by processes of modernisation'. $5^{2}$ To be sure, Sehnsucht bears key traits of the genre's attention to these transformations, including 'often phantasmagoric constructions of place, [a] manifest obsession with questions of displacement and mobility, and [...] 'distanciated relations' that structure the local'. ${ }^{33}$ It might even be argued that its archiving of a swiftly disappearing time and place manifests a kind of nostalgia that is highly characteristic of the Heimatfilm. On the other hand, however, the film's depiction of the precarity of intimacy in the present - the manifest inability of love to triumph over social and economic barriers, the enervation of folkloric traditions in the face of global pop culture's hegemony, and the affective force of longing that does not stick to proper objects_-in tandem with its open ending - jumble the recognizable markers of the Heimatfilm in Sehnsucht.

On Sehnsucht's resignification of the Heimatfilm, see also Wheatley, 'Not Politics but People'.

Elsaesser and Wedel, The BFI Companion to German Cinema, 133.

von Moltke, 'Evergreens: The Heimat Genre', 23.

von Moltke, 'Evergreens: The Heimat Genre', 25. 
This disorganized engagement of genre tropes is especially evident in the film's perhaps most noteworthy sequence, which takes place when Markus, away at the fire brigade training course, gets drunk at an evening banquet. The documentary realism of this sequence, which was shot in a local pub and records speeches by the fire chiefs and snippets of conversations among the volunteers over food and drinks, depicts the culture of village life, with its emphasis on community and the preservation of local traditions like the formal exchange of placards and banners to mark the occasion of the group course. However, this emphasis is suddenly interrupted by an extended long take of the drunken Markus dancing by himself to the 2002 Robbie Williams pop song 'Feel', whose lyrics bespeak the emotions Markus is incapable of expressing out loud and provide a possible explanation for his subsequent actions:

I just wanna feel

Real love feel the home that I live in

'Cause I got too much life

Running through my veins

Going to waste

I don't wanna die

But I ain't keen on living either

Before I fall in love

I'm preparing to leave her

The camera holds tight on Markus dancing for over two minutes, a duration that compels us to observe closely the way he performs masculinity. With his traditional uniform, working-class background, local roots in village life, and embodiment of the 'strong silent type', Markus is in many ways the polar opposite of the transnational businessman whom Connell describes as the emblem of hegemonic masculinity in the neoliberal age, except perhaps in the sense that 'transnational business masculinity differs from traditional bourgeois masculinity by its increasingly libertarian sexuality'. ${ }^{44}$ That is, the neoliberal flexibilization of gender and sexuality registers in Markus not (yet) via practices of self-fashioning but rather as a diffuse longing suggested by the lyrics of 'Feel' and manifested in his dancing. This registering of flexibilization escalates when the dance sequence is abruptly interrupted by a smash cut to a bedroom where we see a disoriented Markus lying alone in bed. When he stumbles into the kitchen and finds Rose there, Markus 
doesn't remember what happened the night before, but Rose's awkward, shy smiles make it clear that they have slept together.

In keeping with the normalization of flexible sexuality that is a hallmark of the present (but in contrast to the screwball comedy or domestic melodrama), Sehnsucht does not present Rose as the opposite number to Ella, nor does it present Markus's affair as especially illicit. Rose hails from precisely the same small-town rural milieu as Ella, and the resemblance of the two characters disorganizes conventional depictions of women on screen (i.e. typical dichotomies of wife/temptress or virgin/whore) in ways that contribute to the film's critical engagement with gender roles and norms. After they spend the night together, Rose brings Markus to a cookout, where she introduces him to her extended family. Here and elsewhere, the observational cinematography and dispassionate formal language of Sehnsucht withhold judgment. While this narrative scenario might lead us to anticipate that Markus will end up with the proper partner, or that the love triangle will facilitate the overt airing of the social contradictions underpinning his inchoate longing, in fact the film's irresolute language thwarts such genre expectations.

The representation of intimacy in Sehnsucht is condensed in a pivotal scene where Markus and Ella go to bed together. Like the other bed sequences discussed in this chapter, this one also serves as a locus for the redefinition of gender and sexual roles in the precarious present. The marital bed in this scene becomes the site not of the consummation of heteronormative relationality but rather of the couple's unbinding from the intimate optimism that has driven their bond until now. The scene takes place after Markus has, unbeknownst to Ella, already begun his affair with Rose. Sitting at the kitchen table drinking schnapps, Ella tells him, 'I'm always thinking about you. About us. When I look at you, I actually lose my breath. I imagine things that we don't usually do. That we look at each other while we are touching. That we talk to each other while we are having sex. I desire you so much.' Ella's direct expression of desire and open discussion of sexual practices departs from normative expectations of rural women as passive, figured by the old-fashioned milieu of the village kitchen where she sits. (This milieu is also captured in several documentary-like sequences throughout the film that attest to the persistence of traditional gender norms and values in Zühlen, recorded in the stories of women's romantic partnerships, such as one woman's tale of the home renovation projects her husband surprised her with each time she returned home from giving birth to one of their children). In the face of Ella's confession of desire, Markus once again finds himself at a loss for words, and he can only respond by repeating his wife's name: 
'Ella...' They kiss and embrace, and again Ella vocally expresses her desire: 'Sleep with me.' As Michael D. Richardson describes it, 'The ensuing scene is long and uncomfortable: it depicts not two lovers familiar with each other's bodies and physically in sync, but rather a pair of strangers: Ella, his wife, desperately reaching out for Markus, hungrily kissing and groping him as if it were their last night together, and Markus, constantly turning his face away from hers and trying to restrain her and keep their physical contact to a minimum.55 Again and again, Markus appears to push Ella away, as if denying her agency, eventually pinning her down as she claws at his head in an expression of intimacy that is ambiguously depicted as aggressive, even violent (see Illustration 14).

This scene serves as a key paradigm for Richardson's diagnosis of the 'bad sex' that permeates Berlin School films: 'Bad sex is but the bodily manifestation of the social alienation that plagues the characters that populate Berlin School cinema. ${ }^{56}$ Richardson is correct in arguing that sex in these films often registers the longing for closeness and connection that their protagonists seek and fail to find; the explicit and often awkward depiction of sex indexes the precarity of intimacy in an era characterized by, as he puts it, the desire for 'a renewed community with others, however impossible that may be'. ${ }^{7}$ Although the label 'bad sex' implies a somewhat misleading binary (what might cinematic representations of 'good sex' look like?), the point remains that Sehnsucht and other Berlin School films are noteworthy for their insistence on portraying nonidealized forms of intimacy as an integral component of ordinary life.

In the case of Sehnsucht, the pivotal bed scene registers how their escalating divergence from normative modes of relationality and sexual partnership places Markus and Ella at odds with one another, in ways that fuel Markus's aggression (aggression that he ultimately turns against himself). The general loosening of intimate attachments charted by the film is underscored by two violent scenes with which the film's main narrative culminates. In the first of these, Markus returns to Rose to tell her that he can't see her anymore, but as they share one final night together in his hotel room, Rose accidentally falls from the hotel balcony several stories down to the ground below, in an utterly unexpected calamity that shocks and disorients Markus and the viewer alike. As at the beginning of the film, Markus finds himself once more standing over an injured 


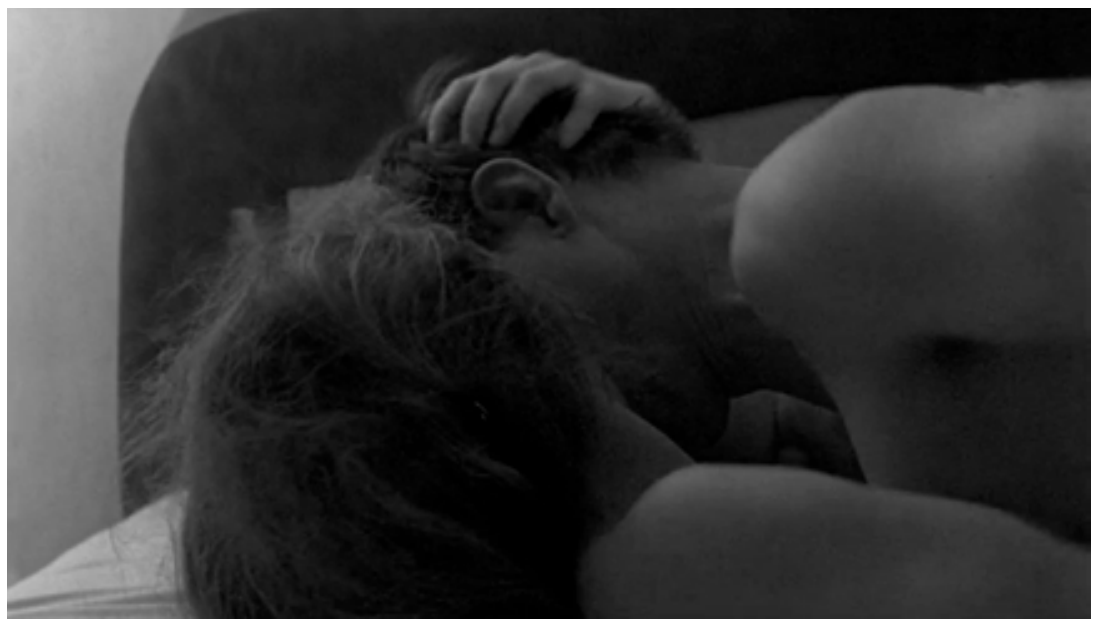

14. Unbinding from intimate optimism in the marital bed: The ambiguous representation of sex between Ella (Ilka Welz) and Markus (Andreas Müller) in Valeska Grisebach's Sehnsucht (Longing, 2006).

body while waiting for an ambulance to arrive; once more he speaks with a police officer in the aftermath of an accident, this time learning that Rose has not authorized the disclosure of her location in hospital because she doesn't want to see Markus, information that somehow implicates him in her injury. As in the film's opening sequence, here again the elliptical editing style of Sehnsucht does not offer us enough information to comprehend Rose's accident, and we must piece together a sense of what has happened through the shards of aural and visual information conveyed by these fragmented scenes. The disorienting formal construction of this sequence emphasizes the violent rupture of Markus's intimate bond with Rose.

Markus's subsequent suicide attempt is similarly conveyed in a manner both shocking and oblique. We see him in his garage building a hutch for his nephew's pet rabbit. Markus hugs and strokes the rabbit, placing it in the cage and offering it grass to munch before loading a shotgun and aiming it at his heart. As we see the rabbit eating, we suddenly hear a gunshot and a quick cut reveals Markus's body falling from the stool he had been sitting on. We only catch the briefest glimpse of him before he disappears from the frame, as the camera holds steady on the empty garage. Unexpected and unexplained, Markus's suicide is open to interpretation as a heartbroken act of desperation, a courageous declaration of culpability, a redirection of the violence of the present toward the self, and/or a symbolic gesture registering the effects on Markus of the crisis of heterosexuality and changing norms of masculinity. 
Underscoring the ambiguity of this penultimate scene, Sehnsucht concludes with an epilogue that explicitly gestures to the multivalent interpretations viewers might bring to its narrative. After Markus is evacuated by helicopter (bringing us back to the opening scene in which the man whom Markus had saved was also loaded into a helicopter), we see a series of static shots depicting trees, buildings, and an empty soccer field. While they are positioned as establishing shots - setting the scene for the action to follow - these images are non-specific, even desolate, serving to unsettle rather than orient us in time and space. The blowing of the wind and the briefly audible call of a cuckoo suggest a moment of transformation, hinting at the fact that Markus will survive.

This sequence provides a segue to the epilogue, which begins with a long shot of a group of adolescents sitting on top of a jungle gym. The camera moves in closer to reveal a girl telling a story, which relates the narrative of the film we have just seen, but in broad strokes that underscore its affinity with the genre of the relationship film. As the girl tells it, a man and a woman are in love, but one day the man, a firefighter, goes off to another town to put out a fire. There, he meets another woman and gets together with her. Although they are happy, he still has feelings for his wife, so he leaves his girlfriend. However, his wife finds out about her husband's affair, and the man is so upset that he shoots himself in the heart (he survives the suicide attempt). At this point, the story breaks off, and the kids respond with different interpretations of the husband's violent act: 'courageous'; 'dumb'; 'romantic'.

A car drives by loudly honking its horn, and a brief cutaway calls our attention to an eye-catching green and yellow fence in the background of the shot, a clue that - although we have never seen the playground in the course of the film-locates the epilogue in the same village where the film's main narrative is set. The girl then concludes the story, 'And now he is back together with one of the women, and guess which one it is', prompting a fierce interchange of guesses among her listeners. One boy proclaims, 'It's fate.' 'Do you even know what fate is?', asks the girl, and he replies, 'Fate is that which one cannot change.' Like the many clichés that pepper the dialogue of the main narrative, this one also fails to capture adequately the events of the story or to clue us into its outcome, an irresolution subsequently affirmed by the film's final shot, which shows the kids walking away from the camera through the quiet streets of the town. As a stand-in for director Grisebach, the girl in the epilogue invites her diegetic audience of friends (and by extension the audience of Sehnsucht), to participate in a process of interpretation, while also insisting on the limitations of narrative to capture the exigencies of reality. 
Widely recognized as a key trait of Berlin School films, open endings feature prominently in what Brad Prager calls the 'aesthetics of irresolution' they develop via a refusal of logical explanations and a formal language (abrupt cuts, static long takes, an aversion to reverse shots) that requires viewers to fill in the many narrative gaps left by the images on screen. As Prager points out, these unresolved endings often pertain to the fate of couples whose relationships face an uncertain future, yoking formal irresolution to stories about failed intimacy: 'Such instances suggest the Berlin School's conviction that conventional cinema, where it provides sense-making endings and clings to the concept of closure, sells reality short. ${ }^{58}$ Exemplary of this tendency, the playful epilogue of Sehnsucht not only denies a clear answer about the outcome of the tragic love triangle but also metacinematically reflects on the enterprise of storytelling and the generic clichés upon which it so often depends, while also winkingly acknowledging the filmmaker's choice to leave the story unresolved. This epilogue demonstrates again how an interrogation of genre forms the ground for a thematic focus on the precarity of intimacy in recent German cinema. Contributing to the aesthetics of irresolution in Sehnsucht, the epilogue also condenses the film's broader attention to the politics and conventions of narrative and genre at present, underscoring a tension the film maps between the codes and expectations of dominant global cinema and the possibilities offered by local forms of expression.

Sehnsucht's remixing of characteristics familiar from German genres such as the Beziehungskomödie and the Heimatfilm together with formal and thematic elements that draw on the legacy of DEFA results in a cinematic language that figures and makes palpable the disorientation that is the focus of its narrative. Like the other films discussed in this chapter, Sehnsucht draws on local genres to trace characters' 'becoming more adjusted to the way capitalism works' (per Dörrie's description of Männer) through a specific focus on the co-existence of traditional and flexible gender roles and the concomitant precaritization of intimacy in the neoliberal age. Reading Sehnsucht together with Männer, Der bewegte Mann, and Coming Out helps to bring into focus how these stylistically divergent films all engage with and often trouble genre while narrating a crisis of heterosexuality that is notably never resolved. While my analysis highlights formal and thematic continuities across this diverse canon of films in order to locate the failing family as a key site for the cinematic engagement with neoliberalism, I do not mean to paper over the substantial differences that obtain among them 
due to the varying production cultures, modes of reception, and aesthetic and political impulses they exhibit.

These differences come into focus through a consideration of the Berlin School (a topic I turn to in more detail in Chapter 6) and the way that Sehnsucht in particular was instrumentalized within debates about its legitimacy as a representative form of German cinema after the demise of the national-cultural film project. An early example of 'second-generation' Berlin School cinema, Sehnsucht debuted in competition at the Berlin Film Festival in February 2006, shortly after the first articles appeared coining the designations Berliner Schule and nouvelle vague allemande to describe an emergent constellation of contemporary German films that shared common traits, including renewed attention to film form and aesthetics and a focus on life during the era of late capitalism and globalization. ${ }^{59}$ Grisebach's film was widely lauded in the press but failed to capture a wide theatrical audience, not least due to limitations in distribution and advertising resulting from its production context. This, to his mind, outsized critical reception relative to its commercial potential led producer Günter Rohrbach to cite Sehnsucht in his polemical essay 'Das Schmollen der Autisten' (The Pouting of the Autistics; see also Chapter 2) as a key example of the wilful failure of German film critics to perform what he believes should comprise their central task: the promotion of (mainstream) German cinema.

For Rohrbach, the fact that critics embraced a low-budget film like Sehnsucht while negatively assessing big-budget popular hits like Tom Tykwer's Das Parfum (Perfume, 2006) or Florian Henckel von Donnersmarck's Das Leben der Anderen (The Lives of Others, 2007, discussed in Chapter 2) presents proof positive of their skewed interests: 'Too frequently they have sent their readers to the wrong movies, too narcissistically they have painted an image of their own cineastic competencies, while forgetting what their central task really is: namely, to offer decision-making assistance for potential

59 See for example Gupta, 'Berliner Schule: Nouvelle Vague Allemande.' The 'first generation' of Berlin School filmmakers comprises Thomas Arslan (b. 1962), Angela Schanelec (b. 1962), and Christian Petzold (b. 1960), who studied directing together at the Deutsche Film- und Fernsehakademie Berlin (dffb), where they were taught by the political filmmakers Hartmut Bitomsky and Harun Farocki. The 'second generation' of Berlin School filmmakers designates a group of slightly younger and less closely affiliated directors whose films share certain affinities, although they did not necessarily study at the dffb, including Grisebach (b. 1968, who studied at the Filmakademie in Vienna), Ulrich Köhler (b. 1969, who studied at the Hochschule der bildenden Künste in Hamburg), and Christoph Hochhäusler (b. 1972) and Maren Ade (b. 1976), both of whom graduated from the Hochschule für Fernsehen und Film in Munich. 
viewers. Instead of placing themselves in the service of the films, they have instead placed the films in the service of their own self-promotion. ${ }^{60}$ Rohrbach therefore designates Germany's film critics as 'autistic', which in his inflated, ableist language appears to serve as a synonym for selfabsorption. Rohrbach inveighs against critics for refusing to support and legitimize what he positively assesses as 'consensus films', attacking the critics for supporting a differentiated film landscape by sending viewers to the 'wrong movies', such as Sehnsucht. Rohrbach's indictment of Sehnsucht amounts, in Abel's words, to an attack on the Berlin School as 'the wrong kind of national cinema', one that seemingly operates at cross purposes to the consensus and heritage films promoted by the film establishment. ${ }^{61}$ As discussed in Chapter 2, Rohrbach's polemic functions as a kind of manifesto for the German cinema of neoliberalism by naturalizing market orientation as cinema's chief ontology and legitimizing force, simultaneously writing off other functions such as cultural representation or aesthetic experimentation.

The Berlin School has served as a key locus for discussions of the status of contemporary (German) cinema, not only for defenders of the mainstream like Rohrbach, but also, of course, for those who view these films as precisely the 'right' kind of national cinema, one that contests the mainstream. Because Berlin School films generally embrace a rigorous narrative and formal style and eschew recourse to principles of plot, narrative, or characterization, their advocates have generally understood these films as countercinema, 'a mode of filmmaking that questions and resists both the plotting and tempo of conventional narrative cinema and, simultaneously, the lifeworld that gave birth to it'. ${ }^{62}$ As Marco Abel argues in his influential study The Counter-Cinema of the Berlin School, these films pursue an 'aesthetic of reduction' and an 'arepresentational' mode of realism that contrast sharply with the formal-aesthetic language of the cinema of consensus: 'the Berlin School films tend to force audiences to come to terms with the demand to resee that with which they assumed sufficient familiarity'. ${ }^{6}$ In this way, they offer an alternative vision of German reality.

Due to their anticonventionalism and austere aesthetics, engagement with genre has generally been seen as an exception in Berlin School films. Indeed, the very explicit embrace of genre by a wide range of

6o Rohrbach, 'Das Schmollen der Autisten.'

61 See Abel, '22 January 2007.'

62 Cook et al., Berlin School Glossary, 1.

63 Abel, The Counter-Cinema of the Berlin School, 15 . 
affiliated filmmakers beginning around 2012 was accompanied by proclamations of the demise of the Berlin School itself, suggesting the overall incompatibility of the movement with genre cinema ${ }^{64}$ From another perspective, however, it is clear that concerted engagement with generic forms has been central to the development of the Berlin School since its inception. Widely hailed as contemporary Germany's 'most critically acclaimed auteur' and part of the first generation of Berlin School directors, Christian Petzold has written and directed numerous feature films all of which pair a rigorous interrogation of European art cinema with a resignification of popular genre cinema (see Chapter 6$).{ }^{65}$ While Petzold provides perhaps the most prominent example of genre's longstanding centrality to the conception of the Berlin School, it also figures significantly in the films of Thomas Arslan (also discussed in Chapter 6) and, notably, in those of many women directors, including Maren Ade, Barbara Albert, Jessica Hausner, Sonja Heiss, and Grisebach, whose Sehnsucht comprises an especially significant early example of the Berlin School's approach to genre.

In contrast to the commercial films endorsed by Rohrbach and other members of the German film establishment, which engage genre as both a mode of entertainment and a stabilizing force in response to neoliberalization, Sehnsucht and other Berlin School films work to destabilize contemporary reality and our ways of perceiving and responding to it, through a range of techniques. These include many of the strategies discussed above, such as observational cinematography, long takes, flat or affectless acting styles, minimal dialogue, refusal of closure, and the common strategy of 'representing emotions without emotionalizing. ${ }^{66}$ These aesthetic techniques are a central vector of the films' ambivalent charting of the disorienting changes that permeate ordinary life in the present, but they also prove crucial to the mode of production developed by the Berlin School's practitioners, since using a minimalist style reduces production costs.

As I have argued elsewhere, the films of the Berlin School may be generatively understood as contemporary media assemblages that combine multiple transnational and national film genres and waves (to name just a few: new realisms, slow cinema, New German Cinema, and feminist cinema, as well

64 See for example Christoph Hochhäusler's proclamation that 'school is out' in his contribution to the exhibition catalog for the 2013 Museum of Modern Art exhibition 'The Berlin School: Films from the Berliner Schule.' Hochhäusler, 'On Whose Shoulders.'

65 Fisher, Christian Petzold, 1.

66 Leweke, 'Gehen und reden', n.p. 
as popular forms and genres such as the thriller, the Western, the heritage film, and especially the Heimatfilm) along with multiple production and exhibition formats (analogue and digital; film, television, and streaming) in order to create a broad-based appeal to an international audience of cineastes. ${ }^{67}$ Such a model helps to conceptualize how Berlin School films are firmly embedded within commercial, mainstream platforms while simultaneously posing a challenge to them. This hybrid quality also helps to account for both the remarkable status Berlin School films have attained in academic and journalistic contexts and for the vehemence of certain hostile reactions they have elicited, for which Rohrbach's attack on Sehnsucht is perhaps the most emblematic.

While critics have tended to address Berlin School films as a closed corpus, viewing them as related to one another (as the emphasis on 'generations' of directors suggests) but as generally separate from and opposed to developments in German cinema more broadly, my analysis in this chapter and the next deliberately reads Berlin School films together with films from which they are usually bracketed off. Doing so draws attention to the significant aesthetic and thematic continuities (as well as differences) that obtain across diverse modes of filmmaking, enabling a better understanding of the intertwined production and viewing contexts of various forms of audiovisual representation in the neoliberal mediascape.

Remakes, reboots, adaptations, and sequels form Global Hollywood's main mode of production today; from Das Boot to Der Untergang (Downfall, 2004) to the Resident Evil series (2002-2016), commercial filmmaking from location Germany has also built its profitability on adaptations and sequels. For directors affiliated with the Berlin School and other filmmakers pursuing resistant aesthetic and political projects, engagement with genre has similarly emerged as a key strategy in the ability of independently produced German films to create a transnational appeal to audience familiarity, allowing them to simultaneously take part in and refuse commercial modes of postcinematic representation. At the same time, genre provides a key horizon for these films to disorganize conventions of portraying desire and identity, fantasy and ordinary life in the neoliberal present, as the films discussed in Chapter 6 also attest. 


\section{Works Cited}

Abel, Marco. '22 January 2007: Film Establishment Attacks "Berlin School" as Wrong Kind of National Cinema.' In A New History of German Cinema. Ed. Jennifer M. Kapczynski and Michael D. Richardson. Rochester, NY: Camden House, 2012. 602-8.

Abel, Marco. The Counter-Cinema of the Berlin School. Rochester, NY: Camden House, 2013 .

Altman, Rick. Film/Genre. London: BFI, 1999.

Baer, Hester. 'The Berlin School and Women's Cinema.' In The Berlin School and its Global Contexts: A Trans-National Art Cinema. Ed. Marco Abel and Jaimey Fisher. Detroit: Wayne State UP, 2018. 25-48.

Berlant, Lauren. Cruel Optimism. Durham: Duke University Press, 2011.

Boovy, Bradley. 'Belonging in Black and White: Race, Photography, and the Allure of Heimat in West German Gay Magazines from the 1950s.' Seminar-AJournal of Germanic Studies 54.4 (2018): 428-441.

Brockmann, Stephen. A Critical History of German Film. Rochester, NY: Camden House, 2010.

Connell, Raewyn. 'Masculinities and Globalization.' Men and Masculinities 1.1 (n.d.): $3-23$.

Cook, Roger F., et al. Berlin School Glossary: An ABC of the New Wave in German Cinema. Chicago: Intellect, 2013.

Dennis, David Brandon. 'Coming Out into Socialism: Heiner Carow's Third Way.' In A Companion to German Cinema. Ed. Terri Ginsberg. Malden, MA: WileyBlackwell, 2012.

Duggan, Lisa. The Twilight of Equality?: Neoliberalism, Cultural Politics, and the Attack on Democracy. Boston: Beacon Press, 2003.

Elsaesser, Thomas, and Michael Wedel. The BFI Companion to German Cinema. London: BFI, 1999.

Fisher, Jaimey. Christian Petzold. Urbana, Ill.: University of Illinois Press, 2013.

Fisher, Jaimey, ed. Generic Histories of German Cinema: Genre and Its Deviations. Rochester, NY: Camden House, 2013.

Frackman, Kyle. 'The East German Film "Coming Out” (1989) as Melancholic Reflection and Hopeful Projection.' German Life and Letters 71.4 (2018): 452-472.

Görtemaker, Manfred. Geschichte der Bundesrepublik Deutschland: von der Gründung bis zur Gegenwart. München: Beck, 1999.

Gupta, Susanne. 'Berliner Schule: Nouvelle Vague Allemande.' Fluter: Magazin der Bundeszentrale für politische Bildung (31August 2005).

Halle, Randall. "Happy Ends" to Crises of Heterosexual Desire: Toward a Social Psychology of Recent German Comedies.' Camera Obscura 15. 2 (2000): 1-39. 
Hochhäusler, Christoph. 'On Whose Shoulders: The Question of Aesthetic Indebtedness.' In The Berlin School: Films from the Berliner Schule. Ed. Rajendra Roy and Anke Leweke. New York: The Museum of Modern Art, 2013. 20-31.

Koch, Gertrud, et al. 'Bei neuestem Licht besehen: Ein Streitgespräch über "Männer” und “Tarot."' Frauen und Film 41 (1986): 84-89.

Leweke, Anke. 'Gehen und reden.' Tip (14 February 2001): n.p.

Mennel, Barbara. Women at Work in Twenty-First-Century European Cinema. Urbana, Ill.: University of Illinois Press, 2019.

von Moltke, Johannes. 'Evergreens: The Heimat Genre.' In The German Cinema Book. Ed. Tim Bergfelder, Erica Carter, and Deniz Göktürk. London: BFI, 2002. 18-28. Mukhida, Leila. 'Violence in the Age of Digital Reproducibility: Political Form in Valeska Grisebach's Longing (2006).' German Politics \& Society 33.1-2 (2015): 172-185. https://doi.org/10.3167/gps.2015.330113.

Phillipps, Klaus. 'A Conversation with Doris Dörrie.' In Straight through the Heart: Doris Dörrie, German Filmmaker and Author. Ed. Franz Birgel and Klaus Phillipps. Lanham, MD: Scarecrow Press, 2004. 1-16.

Prager, Brad. 'Endings.' In Berlin School Glossary: An ABC of the New Wave in German Cinema. Ed. Roger F. Cook et al. Chicago: Intellect, 2013. 109-116.

Richardson, Michael D. 'Bad Sex.' In Berlin School Glossary: An ABC of the New Wave in German Cinema. Ed. Roger F. Cook et al. Chicago: Intellect, 2013 41-49. Römers, Holger. 'Männer/Men.' In The Cinema of Germany. Ed. Joseph Garncarz and Annemone Ligensa. London: Wallflower Press, 2012. 206-215.

Rohrbach, Günter. 'Das Schmollen der Autisten.' Der Spiegel (22 January 2007).

Schenk, Ralf. 'Aus der Mitte des Lebens. Eine Umfrage zur DEFA, ihren Traditionen und deren Wert für das heutige Kino.' Film-Dienst Sonderheft (10/2006). http:// www.defa-stiftung.de/docs/attachments/3e62fbob-77a3-4ca8-8f35-03092a81d78f/ Aus-der-Mitte-des-Lebens.-Eine-Umfrage-zur-DEFA-ihren-Traditionen-undderen-Wer.pdf. Accessed 12 August 2016.

Shaviro, Steven. Post-Cinematic Affect. Winchester, UK: o [zero] Books, 2010.

Sieg, Katrin. 'Homosexualität und Dissidenz: Zur Freiheit der Liebe in Coming Out von Heiner Carow.' In Die Imaginierte Nation: Identität, Körper und Geschlecht in DEFA-Filmen. Ed. Bettina Mathes. Berlin: DEFA-Stiftung, 2007. 284-310.

Treiblmayr, Christopher. Bewegte Männer: Männlichkeit und männliche Homosexualität im deutschen Kino der 199oer Jahre. Cologne: Böhlau, 2015.

Wheatley, Catherine. 'Not Politics but People: The "Feminine Aesthetic" of Valeska Grisebach and Jessica Hausner'. In New Austrian Film. Ed. Robert von Dassanowsky and Oliver C. Speck. New York: Berghahn Books, 2011. 136-147.

Woltersdorff, Volker. 'Paradoxes of Precarious Sexualities.' Cultural Studies 25. 2 (2011): 164-82. https://doi.org/10.1080/09502386.2011.535984. 